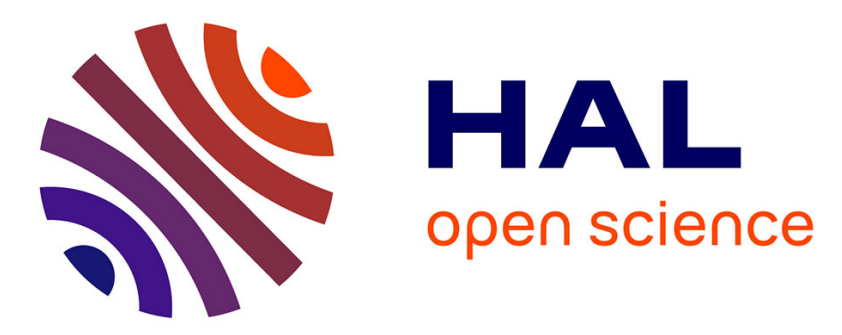

\title{
Interaction of Cisplatin with Adenine and Guanine: A Combined IRMPD, MS/MS, and Theoretical Study
}

\author{
Barbara Chiavarino, Maria-Elisa Crestoni, Simonetta Fornarini, Debora
}

Scuderi, Jean-Yves Salpin

\section{To cite this version:}

Barbara Chiavarino, Maria-Elisa Crestoni, Simonetta Fornarini, Debora Scuderi, Jean-Yves Salpin. Interaction of Cisplatin with Adenine and Guanine: A Combined IRMPD, MS/MS, and Theoretical Study. Journal of the American Chemical Society, 2013, 135 (4), pp.1445-1455. 10.1021/ja309857d . hal-00796084

\section{HAL Id: hal-00796084 https://hal.science/hal-00796084}

Submitted on 5 Oct 2018

HAL is a multi-disciplinary open access archive for the deposit and dissemination of scientific research documents, whether they are published or not. The documents may come from teaching and research institutions in France or abroad, or from public or private research centers.
L'archive ouverte pluridisciplinaire HAL, est destinée au dépôt et à la diffusion de documents scientifiques de niveau recherche, publiés ou non, émanant des établissements d'enseignement et de recherche français ou étrangers, des laboratoires publics ou privés. 


\section{Interaction of cisplatin with adenine and guanine: a combined IRMPD, MS/MS and theoretical study}

Barbara Chiavarino ${ }^{1 *}$, Maria Elisa Crestoni ${ }^{1}$, Simonetta Fornarini ${ }^{1}$, Debora Scuderi ${ }^{2,3}$ and Jean-Yves Salpin ${ }^{4,5 *}$

1) Dipartimento di Chimica e Tecnologie del Farmaco, Università di Roma "La Sapienza", P.le A. Moro 5, I-00185 Roma, ITALY

2) Université Paris Sud Orsay - Laboratoire de Chimie-Physique - Avenue Georges Clémenceau - 91405 Orsay Cedex - FRANCE

3) CNRS- UMR 8000.

4) Université d'Evry Val d'Essonne - Laboratoire Analyse et Modélisation pour la Biologie et l'Environnement - Boulevard François Mitterrand - 91025 Evry - FRANCE

5) CNRS- UMR 8587.

Corresponding authors:

Dr Barbara Chiavarino

e-mail: barbara.chiavarino@uniroma1.it

Dr Jean-Yves Salpin

e-mail: jean-yves.salpin@univ-evry.fr 


\begin{abstract}
IR multiple photon dissociation spectroscopy of cis-[Pt( $\left.\left(\mathrm{NH}_{3}\right)_{2}(\mathrm{G}) \mathrm{Cl}\right]^{+}$and cis$\left[\mathrm{Pt}\left(\mathrm{NH}_{3}\right)_{2}(\mathrm{~A}) \mathrm{Cl}\right]^{+}$ions (where $\mathrm{A}$ is adenine and $\mathrm{G}$ is guanine) has been performed in two spectral regions, namely 950-1900 $\mathrm{cm}^{-1}$ and 2900-3700 $\mathrm{cm}^{-1}$. Quantum chemical calculations at the B3LYP/LACV3P/6-311G** level, yield the optimized geometries and IR spectra for the conceivable isomers of cis- $\left[\mathrm{Pt}\left(\mathrm{NH}_{3}\right)_{2}(\mathrm{G}) \mathrm{Cl}\right]^{+}$and $c i s-\left[\mathrm{Pt}\left(\mathrm{NH}_{3}\right)_{2}(\mathrm{~A}) \mathrm{Cl}\right]^{+}$, whereby the cisplatin residue is attached to either the N7, N3 or to the carbonyl oxygen atom (O6) of guanine, and either to the N7, N3 or N1 position of adenine, respectively. In addition to the conventional binding sites of native adenine, complexes with $\mathrm{N} 7-\mathrm{H}$ tautomers have also been considered. In agreement with computational results the IR characterization of cis- $\left[\mathrm{Pt}\left(\mathrm{NH}_{3}\right)_{2}(\mathrm{G}) \mathrm{Cl}\right]^{+}$points to a covalent structure where $\mathrm{Pt}$ is bound to the N7 atom of guanine. The characterized conformer has a hydrogen bonding interaction between a hydrogen atom of one $\mathrm{NH}_{3}$ ligand and the carbonyl group of guanine. The experimental $\mathrm{C}=\mathrm{O}$ stretching feature of $c i s-\left[\mathrm{Pt}\left(\mathrm{NH}_{3}\right)_{2}(\mathrm{G}) \mathrm{Cl}\right]^{+}$at $1718 \mathrm{~cm}^{-1}$, remarkably redshifted with respect to an unperturbed $\mathrm{C}=\mathrm{O}$ stretching mode, is indicative of a lengthened $\mathrm{CO}$ bond in guanine, a signature that this group is involved in hydrogen bonding. The IRMPD spectra of $c i s-\left[\mathrm{Pt}\left(\mathrm{NH}_{3}\right)_{2}(\mathrm{~A}) \mathrm{Cl}\right]^{+}$are consistent with the presence of two major isomers, PtAN3 and PtAN1, where Pt is bound to the N3 and N1 positions of native adenine, respectively.
\end{abstract}




\section{Introduction.}

Cis-diamminedichloroplatinum(II), commonly known as cisplatin (cis-[ $\left.\left.\mathrm{Pt}\left(\mathrm{NH}_{3}\right)_{2} \mathrm{Cl}_{2}\right]\right)$, is a widely-used anticancer drug that has been particularly successful in treating different types of tumors (lung, ovarian, testicular, head, and neck). ${ }^{1}$ Since its discovery some 40 years ago, ${ }^{2,3}$ many efforts have been devoted to understand the mechanisms associated with its antitumor activity, ${ }^{4,5}$ which are nowadays quite well established. The primary target of cisplatin is genomic DNA, and more especially the N7 position of guanine bases. Cisplatin enters the cell by passive diffusion through the cell membrane. The biologically active substrate, namely cis- $\left[\mathrm{Pt}\left(\mathrm{NH}_{3}\right)_{2}\left(\mathrm{H}_{2} \mathrm{O}\right) \mathrm{Cl}\right]^{+}$is then formed within the cell, a process promoted by the low chloride concentration inside the cell. It interacts with a guanine residue at the N7 position, thereby generating the monofunctional adduct by loss of water. In a subsequent step, the second chlorine atom is expelled and coordination to the N7 position of an adjacent purine results in what is called an intrastrand cross-link. ${ }^{6,7}$ These intra-strand cross-links are mainly 1,2-d(GpG) and to a lesser extent 1,2-d(ApG). 1,2-intrastrand cross-links structurally distort the DNA duplex ${ }^{8,9}$ and ultimately lead to the genotoxicity and antitumor activity.

In spite of the clinical success of cisplatin, side effects, natural and acquired resistance of patients toward the drug have motivated searches for structurally and/or functionally analogous alternatives. Unfortunately, finding analogous compounds that outperform cisplatin has proved to be difficult. Thousands of platinum compounds have indeed been synthesized during more than four decades. However, only few new agents such as oxaliplatin, carboplatin, and nedaplatin ${ }^{5}$ have been registered worldwide and entered clinical practice. Although there is no doubt that a $\mathrm{Pt}-\mathrm{N} 7$ bond forms during initial attack, the exact structure of the monofunctional adduct is not well known. In this context, a better understanding at the molecular level of the interactions between the Pt and DNA building blocks is thought to be helpful in establishing a new strategy to design cisplatin analogues. 
Such information may be accessible through gas-phase studies, and the present paper is the first of a series of articles dealing with the experimental structural characterization of cisPt/DNA components in the gas phase. We opted for a strategy based upon the gradual increase of the size of the nucleic acid building blocks. We presently report the structural characterization of gas-phase complexes arising from the interaction between cisplatin and the two nucleobases known to be involved in cross-links, namely guanine and adenine.

To perform this study, we combined tandem mass spectrometry experiments with theoretical DFT calculations, and also recorded the IRMPD (Infrared Multiple Photon Dissociation) spectra of the ESI-generated complexes. IRMPD spectroscopy of massselected ions is now established as a powerful approach for the structural characterization of gaseous ions ${ }^{10-15}$ and notably nucleotides, ${ }^{16}$ and has been successfully applied to metal ion/biomolecules systems. ${ }^{12,17-32}$ This ion spectroscopy is often termed "action spectroscopy" since resonant IR absorption cannot be directly probed due to the low ion density within mass spectrometers. Nevertheless, through the use of intense infrared sources, ion fragmentation can be induced by a multiple photon absorption process. Two distinct energy domains were considered. First, IRMPD spectra were recorded in the $950-1900 \mathrm{~cm}^{-1}$ energy region by combining the CLIO (Centre Laser Infrarouge d'Orsay) free electron laser to a FT-ICR instrument. Infrared spectra in the $2900-3700 \mathrm{~cm}^{-1}$ frequency range were also recorded using an optical parametric oscillator (OPO) laser. This spectral range is of particular interest for probing the vibrational shifts associated to the $\mathrm{NH}$ and $\mathrm{OH}$ stretches involved in hydrogen bonds.

\section{Experimental}

\subsection{Materials}

Cis-diamminedichloroplatinum(II) (cisplatin), 2'-deoxyadenosine-5'-monophosphate (5'dAMP), 2'-deoxyguanosine-5'-monophosphate (5'-dGMP) and water used in this work were 
research grade products from commercial sources (Sigma-Aldrich s.r.l. Milan, Italy) and were used without any further purification. Stock aqueous solutions of cisplatin and of the two deoxynucleotides were prepared at $10^{-3} \mathrm{M}$ concentrations. In order to generate the complexes of interest in the gas phase, deoxynucleotides were used instead of the nucleobases given the poor solubility of the latter in any solvent. A $10^{-4} \mathrm{M}$ water solution of cisplatin and analyte (5'-dGMPor 5'-dAMP) were mixed together in the molar ratio of $(1: 1)$ and then allowed to react at room temperature for $24 \mathrm{~h}$, to allow the formation of the different complexes before the analysis. In order to obtain the mixed complex $[\operatorname{Pt}(\mathrm{A})(\mathrm{G})(-$ $\mathrm{H})]^{+}$(A:adenine; G:guanine), an aqueous solution with final concentration of $10^{-4} \mathrm{M}$ was prepared by mixing the three stock solutions of cisplatin, 5'-dGMP and 5'-dAMP in the molar ratio $(1: 1: 1)$ and allowed to react for at least 20 days at room temperature prior to analysis.

\subsection{CID and IRMPD experiments}

Gaseous ions were generated using an electrospray ionization (ESI) source through direct infusion by a syringe pump. CID experiments at variable energy were carried out using a 2000 Q-Trap instrument (Applied Biosystems), a commercial hybrid triple quadrupole linear ion trap mass spectrometer (Q1q2Q $\mu \mathrm{l} / \mathrm{min}$, a declustering potential set to $90 \mathrm{~V}$, and an entrance potential of $8 \mathrm{~V}$. The ion of interest was mass-selected using Q1. CID experiments were performed in the quadrupole collision cell q2 at variable collision energies $\left(\mathrm{E}_{\mathrm{lab}}=5-50 \mathrm{eV}\right)$ with $\mathrm{N}_{2}$ as collision gas at a nominal pressure of $3.3 \times 10^{-5}$ mbar. The dissociation product pattern was monitored by scanning $\mathrm{Q}_{\text {LIT }}$ using the enhanced mode operation where the ions, formed in collision cell $\mathrm{q} 2$, are trapped in $\mathrm{Q}_{\mathrm{Lit}}$ for 10 accumulation spectra in order to increase both the resolution and intensity. A certain extent of fragmentation products, which did not appreciably change in the early steps of increasing $E_{\text {lab }}$, was observed even at the lowest $E_{\text {lab }}$ value of $5 \mathrm{eV}$ that 
was allowed by the instrumental parameters. This early dissociation is ascribed to the presence of collision gas not only in q2 but also in the region between Q1 and q2. ${ }^{33-35}$ This explanation is supported by the pressure dependence of the relative fraction of these products. Quantitative threshold information is not directly amenable. ${ }^{27,33,36,37}$ However, for a comparative analysis of the energy-dependent CID experiments, the collision energies were converted to the center-of-mass frame $\mathrm{E}_{\mathrm{CM}}=[\mathrm{m} /(\mathrm{m}+\mathrm{M})] \mathrm{E}_{\mathrm{lab}}$, in which $\mathrm{m}$ and $\mathrm{M}$ are the masses of the collision gas and of the ion, respectively. Relative abundances of fragment ions display an energy dependence that can be modelled by a sigmoid function and phenomenological appearance energies may be derived from linear extrapolation of the rise of the sigmoid curves to the baseline. ${ }^{33,38,39}$

IRMPD experiments on cis-[Pt( $\left.\left(\mathrm{NH}_{3}\right)_{2}(\mathrm{~A}) \mathrm{Cl}\right]^{+}$and $c i s-\left[\mathrm{Pt}\left(\mathrm{NH}_{3}\right)_{2}(\mathrm{G}) \mathrm{Cl}\right]^{+}$ions have been performed in two spectral regions, namely $950-1900 \mathrm{~cm}^{-1}$ and $2900-3700 \mathrm{~cm}^{-1}$, using two different IR radiation sources, the free electron laser (FEL) at the Centre Laser Infrarouge d'Orsay (CLIO) facility and an Optical Parametric Oscillator/Amplifier (OPO/OPA) laser system at the Università di Roma "La Sapienza", respectively. The FEL radiation is generated by a 10-50 MeV electron linear accelerator and is delivered in $8 \mu$ s-long macropulses at a repetition rate of $25 \mathrm{~Hz}$, each containing few hundred micropulses (few picoseconds long). Typical macropulse energies are $40 \mathrm{~mJ}$. Ions were irradiated for $250 \mathrm{~ms}$ to $1 \mathrm{sec}$ with the IR FEL radiation. For the present study, the FEL was operated at $45 \mathrm{MeV}$ in order to optimize the laser power in the frequency region of interest. The laser wavelength profile was monitored at each reading with a monochromator associated with a pyroelectric detector array (spiricon).

FEL-based experiments were performed using a hybrid FT-ICR tandem mass spectrometer (APEX-Qe Bruker) equipped with a 7.0 T actively shielded superconducting magnet and a quadrupole-hexapole interface for mass-filtering and ion accumulation, under control by the 
commercial software APEX 1.0. This particular experimental setup has already been described in details elsewhere. ${ }^{40}$ cis- $\left[\mathrm{Pt}\left(\mathrm{NH}_{3}\right)_{2}(\mathrm{~A}) \mathrm{Cl}\right]^{+}$and $c i s-\left[\mathrm{Pt}\left(\mathrm{NH}_{3}\right)_{2}(\mathrm{G}) \mathrm{Cl}\right]^{+}$ions were mass-selected in the quadrupole and accumulated in a hexapole containing argon buffer gas for $0.5 \mathrm{sec}$ for collisional cooling. Ions are then pulse-extracted towards the ICR cell where mass-selection of the complexes is performed. They are then irradiated with IR light, after which the resulting ions are mass-analyzed.

An Optical Parametric Oscillator/Amplifier (OPO/OPA) (LaserVision) coupled to a Paul ion trap tandem mass spectrometer Esquire 6000+ (Bruker Inc), has been employed to explore the $2900-3700 \mathrm{~cm}^{-1}$ spectral region of the different species under study. This parametric converter is pumped by a non seeded Nd:YAG laser (Continuum Surlite II) operating at $10 \mathrm{~Hz}$ repetition rate. The typical pulse width of this pump laser is 4-6 ns with output pulse energy of $600 \mathrm{~mJ}$ at $1064 \mathrm{~nm}$. The OPO/OPA laser is tunable within 2800$4000 \mathrm{~cm}^{-1}$ and tunability is achieved by angle fine adjusting of OPO and OPA crystals simultaneously. The angle tuning is controlled precisely using software controlled stepping motors. The typical output energy from the OPO/OPA laser was $20 \mathrm{~mJ} / \mathrm{pulse}$ in the investigated spectral range with $3-4 \mathrm{~cm}^{-1}$ bandwidth. IR beam focussing is performed to achieve better overlap with the trapped ion cloud. In the trap, ions were accumulated for 5$50 \mathrm{msec}$ prior to IR irradiation. Multistage mass spectrometry is performed using the standard Bruker Esquire Control (v5.2) software. The typical irradiation time used in the experiment is 0.5 to $2 \mathrm{sec}$. The irradiation time is controlled using an electromechanical shutter synchronized precisely with the mass spectrometer.

The IRMPD spectrum is obtained by plotting the photofragmentation yield $R(R=-$ $\ln \left[I_{\text {parent }} /\left(I_{\text {parent }}+\Sigma I_{\text {fragment }}\right)\right]$ where $I_{\text {parent }}$ and $I_{\text {fragment }}$ are the integrated intensities of the mass peaks of the precursor and of the fragment ions, respectively) as a function of the frequency of the IR radiation. ${ }^{41} \mathrm{~A}$ recent study $^{42}$ has demonstrated that this data treatment allows a 
better comparison with calculated infrared absorption spectra and a better spectral resolution than other analysis methods such as recording a depletion spectrum or calculating a photodissociation yield.

\subsection{Computational Details}

Molecular orbital calculations were carried out using the $\mathrm{B} 3 \mathrm{LYP}^{43,44}$ density functional, as implemented in the Gaussian-03 set of programs. ${ }^{45}$ The different forms considered have been optimized with the $6-311 \mathrm{G}^{* *}$ basis set, without any symmetry constraint. In order to describe the metallic center, we used the Los Alamos effective core potential (ECP) in combination with the LACV3P** basis set. ${ }^{46-48}$ Harmonic vibrational frequencies were estimated at this level to characterize the stationary points as local minima or saddle points, and to estimate the zero-point vibrational energy ( $\mathrm{ZPE})$ corrections. In the perspective of studying bigger systems, B3LYP/6-31G** calculations have been also performed, Pt being described either with the SKBJ ECP+basis sets ${ }^{49}$ or the LANL2DZ approach. ${ }^{46-48}$ It turned out that both the relative energies and vibrational spectra are similar, regardless of the pseudo-potential and basis sets used to perform the calculations.

The infrared absorption spectra of the various structures were calculated within the harmonic approximation. As far as the positions of the absorption bands are concerned, a scaling factor value of 0.974 has been chosen in the $950-1900 \mathrm{~cm}^{-1}$ region while a value 0.957 is used in the $2900-3700 \mathrm{~cm}^{-1}$ frequency range. Finally, to be consistent with the experimental spectral resolution, the calculated absorption lines have been convoluted with a Gaussian profile of $15 \mathrm{~cm}^{-1}$ FWHM (full width at half maximum) in the $950-1900 \mathrm{~cm}^{-1}$ region, while a FWHM of $5 \mathrm{~cm}^{-1}$ was used for the $2900-3700 \mathrm{~cm}^{-1}$ frequency range. As a final point, the relative stability in solution of the various complexes has also been evaluated by using the Polarized Continuum Model (PCM) in order to take into account the water solvent. 
Throughout this paper total energies are expressed in Hartrees and relative energies in $\mathrm{kJ}$ $\mathrm{mol}^{-1}$. For the sake of simplicity, the basis set used for Pt will be referred to as $6-311 \mathrm{G}^{* *}$. Detailed geometries (Cartesian coordinates) of all the structures mentioned in this paper are available from the authors upon request.

\section{Results and Discussion}

\subsection{Collision-induced dissociation experiments}

Formation of both cis- $\left[\mathrm{Pt}\left(\mathrm{NH}_{3}\right)_{2}(\mathrm{~A}) \mathrm{Cl}\right]^{+}$and cis- $\left[\mathrm{Pt}\left(\mathrm{NH}_{3}\right)_{2}(\mathrm{G}) \mathrm{Cl}\right]^{+}$adducts results from the reaction taking place in a solution containing cisplatin together with either 2'deoxyadenosine-5'-monophosphate (5'-dAMP) or 2'-deoxyguanosine-5'-monophosphate (5'-dGMP) during a $24 \mathrm{~h}$ incubation period. In this process, likely steps comprise the hydration of cisplatin through the displacement of a chloride ion by a water molecule and hydrolysis of the deoxynucleotide. It may be noted that this indirect way of obtaining A and $\mathrm{G}$ adducts using a solution containing the corresponding deoxynucleotide as a source of the nucleobase overcomes the problem of the scant solubility of the native nucleobase. The complexes of interest are formed together with other species containing both ( $5^{\prime}$-dGMP) or (5'-dAMP) or their derivatives bound with cisplatin ions. When the 1:1 mixture of cisplatin and 5'-dGMP is analyzed after $24 \mathrm{~h}$ incubation time, under usual ESI conditions, an intense cluster signal is observed at $\mathrm{m} / \mathrm{z} \quad 414-420$ consistent with the formation of cis$\left[\mathrm{Pt}\left(\mathrm{NH}_{3}\right)_{2}(\mathrm{G}) \mathrm{Cl}\right]^{+}$(Figure S1a of the supporting information). ${ }^{50}$ The simultaneous presence of one chlorine and one platinum atom in the ion yields a characteristic isotopic pattern, easily distinguishable from any one corresponding to Pt-complexes devoid of a chlorine atom. Under similar conditions, the corresponding cis- $\left[\mathrm{Pt}\left(\mathrm{NH}_{3}\right)_{2}(\mathrm{~A}) \mathrm{Cl}\right]^{+}$complex $(\mathrm{m} / \mathrm{z}$ 398404) is formed, as evidenced in Figure S1b.

The $c i s-\left[\mathrm{Pt}\left(\mathrm{NH}_{3}\right)_{2}(\mathrm{G}) \mathrm{Cl}\right]^{+}$adduct ions have been examined by collision-induced dissociation (CID) at variable collision energy, in a hybrid triple quadrupole linear ion trap mass 
spectrometer. The CID spectra were recorded for the selected precursor ion at $\mathrm{m} / \mathrm{z} 415$, holding ${ }^{195} \mathrm{Pt}$ and ${ }^{35} \mathrm{Cl}$ isotopes. The variation of the relative abundances of both precursor and fragment ions with respect to the center-of-mass collision energy $\left(\mathrm{E}_{\mathrm{CM}}\right)$ is given in Figure S2 of the supporting information. As can be seen from Figure S2, the CID spectrum of the cis- $\left[{ }^{195} \mathrm{Pt}\left(\mathrm{NH}_{3}\right)_{2}(\mathrm{G})^{35} \mathrm{Cl}\right]^{+}$ion $(\mathrm{m} / \mathrm{z}, 415)$ exhibits a primary fragment at $\mathrm{m} / \mathrm{z}, 398$ associated with the loss of one molecule of ammonia. One may note that this fragment ion is already present at the lowest collision energy. Four ions are also detected at higher $\mathrm{E}_{\mathrm{CM}}$, namely $m / z 381,353,317$ and 152 . These fragmentations can be ascribed to subsequent processes originating from the ion at $\mathrm{m} / z, 398 .{ }^{50}$ The fragment ion detected at $\mathrm{m} / \mathrm{z}, 381$ corresponds to loss of the second ammonia molecule, while the ion at $\mathrm{m} / \mathrm{z}, 353$ is due to the combined elimination of $\mathrm{NH}_{3}$ and $\mathrm{CO}$. The fragment ion at $\mathrm{m} / \mathrm{z} 317$ may be attributed to the elimination of $\mathrm{HCl}$ from $\mathrm{m} / \mathrm{z} 353$ while the ion detected at $\mathrm{m} / \mathrm{z} 152$ corresponds to protonated guanine $\mathrm{GH}^{+}$.

Likewise the CID of the adenine complex, cis-[Pt( $\left.\left(\mathrm{NH}_{3}\right)_{2}(\mathrm{~A}) \mathrm{Cl}\right]^{+}$, showed similar characteristics. Again, the monoisotopic ion at $\mathrm{m} / \mathrm{z} 399$ containing ${ }^{195} \mathrm{Pt}$ and ${ }^{35} \mathrm{Cl}$ has been mass-selected as precursor ion for CID studies. The variation of the ion intensity of both precursor and fragment ions as a function of $\mathrm{E}_{\mathrm{CM}}$ is provided in Figure $\mathrm{S} 3$ of the supporting information. The MS/MS spectrum of the cis-[Pt( $\left.\left(\mathrm{NH}_{3}\right)_{2}(\mathrm{~A}) \mathrm{Cl}\right]^{+}$complex is characterized by two main dissociation processes. As observed from the guanine complex, the first dissociation product corresponds to the loss of ammonia, yielding the ion at $\mathrm{m} / \mathrm{z}, 382$. The second one at $\mathrm{m} / \mathrm{z} 346$ is due to the elimination of a $\mathrm{HCl}$ molecule. Three additional fragment ions are also detected, which arise from higher energy processes following the primary loss of $\mathrm{NH}_{3}$. Elimination of a second molecule of ammonia leads to the $\mathrm{m} / z, 365$ ion. The species detected at $\mathrm{m} / \mathrm{z}, 329$ may be attributed to loss of both ammonia and hydrochloric acid whereas the ion at $m / z, 136$ corresponds to protonated adenine. 
From these comparative CID experiments, in the case of $c i s-\left[\mathrm{Pt}\left(\mathrm{NH}_{3}\right)_{2}(\mathrm{G}) \mathrm{Cl}\right]^{+}$ion one may envision the presence of a hydrogen bond between a molecule of ammonia of the cisplatin moiety and the guanine carbonyl oxygen, that might account for the fragment ion generated at $m / z 353$ by the simultaneous loss of ammonia and $\mathrm{CO}$, that is peculiar to this complex. Similarly, the concomitant loss of $\mathrm{NH}_{3}$ and $\mathrm{HCl}$ from the cis- $\left[\mathrm{Pt}\left(\mathrm{NH}_{3}\right)_{2}(\mathrm{~A}) \mathrm{Cl}\right]^{+}$adduct may suggest the presence of a hydrogen bond between a N-H group of adenine and the Pt-bound chlorine. $^{50}$

To gain a qualitative idea of the energy involved in cisplatin bonding to either adenine or guanine, energy-dependent CID experiments have been performed on ions generated by the loss of the first ammonia molecule. In fact both ions are found to yield the respective protonated nucleobase by CID. The energy-dependent CID of $\left[\mathrm{Pt}\left(\mathrm{NH}_{3}\right)(\mathrm{G}) \mathrm{Cl}\right]^{+}$is displayed in Figure 1a.

It is worth mentioning that all secondary fragments observed in the MS/MS spectra of cis$\left[\mathrm{Pt}\left(\mathrm{NH}_{3}\right)_{2}(\mathrm{G}) \mathrm{Cl}\right]^{+}$are present in these CID experiments. Linear extrapolation of the rise of the sigmoid curve yields a phenomenological threshold energy $\left(\mathrm{E}_{\mathrm{PT}}\right)$ of $1.55 \pm 0.2 \mathrm{eV}(148$ $\pm 20 \mathrm{~kJ} \mathrm{~mol}^{-1}$ ) for the appearance of $\mathrm{GH}^{+}$. Although the breaking of the cisplatin-guanine bond requires a higher energy compared to the other fragments, protonated guanine becomes the principal fragment with increasing $\mathrm{E}_{\mathrm{CM}}$. The energy-dependent $\mathrm{CID}$ of $\left[\mathrm{Pt}\left(\mathrm{NH}_{3}\right)(\mathrm{A}) \mathrm{Cl}\right]^{+}$is showed in Figure $1 \mathrm{~b}$. The value of the phenomenological threshold energy for the appearance of the protonated adenine ions is $1.38 \pm 0.2 \mathrm{eV}\left(132 \pm 20 \mathrm{~kJ} \mathrm{~mol}^{-}\right.$ ${ }^{1}$ ). Although this extrapolation does not provide by any means a direct measure of the threshold energy for dissociation, it suggests though that cisplatin is more strongly bound to guanine than to adenine.

As a last piece of information, the mixed complex $[\mathrm{Pt}(\mathrm{A})(\mathrm{G})(-\mathrm{H})]^{+}$was also studied by CID. Its formation is not trivial. An aqueous solution containing cisplatin, (5'-dGMP) and (5'- 
dAMP) in 1:1:1 molar ratio needs to be stored at room temperature for more than 20 days in order for the reaction to proceed, yielding the mixed adduct observed by ESI-MS. The full scan ESI spectrum of this mixture is given in Figure S1c. The solution thus prepared showed two main cluster ions, the first centered around $\mathrm{m} / \mathrm{z}, 497$ corresponding to adduct $\left[\mathrm{Pt}\left(\mathrm{NH}_{3}\right)(\mathrm{A})(\mathrm{G})(-\mathrm{H})\right]^{+}$and the other detected around $\mathrm{m} / \mathrm{z} 480$ which corresponds to $[\mathrm{Pt}(\mathrm{A})(\mathrm{G})(-\mathrm{H})]^{+}$. We focused our attention on the latter complex which may yield an insight about whether platinum is preferentially bound to either adenine or guanine. The presence of ammonia in the former complex may induce complicating effects arising from the possibility of hydrogen bonding interactions between $\mathrm{NH}_{3}$ and the nucleobases. CID experiments at variable CE have been conducted on the ion at $m / z 480$, which contains the ${ }^{195} \mathrm{Pt}$ isotope. Two different dissociation channels were observed, leading to protonated adenine and protonated guanine, as displayed in Figure 1c. Phenomenological threshold energy $\left(\mathrm{E}_{\mathrm{PT}}\right)$ values of $1.17 \pm 0.20 \mathrm{eV}\left(112 \pm 20 \mathrm{~kJ} \mathrm{~mol}^{-1}\right)$ and of $1.46 \pm 0.20 \mathrm{eV}(140 \pm 20$ $\mathrm{kJ} \mathrm{mol}^{-1}$ ) are deduced for the fragmentation processes leading to protonated adenine and protonated guanine, respectively. In the event that the energetics of the competitive fragmentation processes were governed by the relative proton affinity of the two bases, a bias could be expected for the formation of protonated guanine. In fact the gas-phase proton affinity (PA) of guanine $\left(959.5 \mathrm{~kJ} \mathrm{~mol}^{-1}\right)^{51}$ is higher than the PA of adenine $\left(942.9 \mathrm{~kJ} \mathrm{~mol}^{-}\right.$ $\left.{ }^{1}\right)^{51}$. Consequently, the CID data would rather suggest that in the $[\mathrm{Pt}(\mathrm{A})(\mathrm{G})(-\mathrm{H})]^{+}$complex guanine is more strongly bound than adenine. Thus, one may argue that the preference of cisplatin toward guanine may be related not only to the strong hydrogen bond that can be established between a hydrogen atom of the ammonia ligand and the oxygen atom of guanine (a stronger hydrogen bond than the one involving either $\mathrm{N}$ atom of adenine as electron density donor), but also to intrinsic features of the Pt bonding, favoring guanine relative to adenine. 


\subsection{IRMPD spectroscopy of $c i s-\left[\mathrm{Pt}\left(\mathrm{NH}_{3}\right)_{2}(\mathrm{G}) \mathrm{Cl}\right]^{+}$complex}

The main purpose of this work is to elucidate and characterize the structure of the cis$\left[\mathrm{Pt}\left(\mathrm{NH}_{3}\right)_{2}(\mathrm{G}) \mathrm{Cl}\right]^{+}$and cis- $\left[\mathrm{Pt}\left(\mathrm{NH}_{3}\right)_{2}(\mathrm{~A}) \mathrm{Cl}\right]^{+}$ions taken as simple models of mono-adducts between cisplatin and DNA, by IRMPD spectroscopy. To this end, IRMPD spectra were recorded in two different spectral regions, in the so-called fingerprint region $(950-1900$ $\left.\mathrm{cm}^{-1}\right)$, using the beamline of the IR-FEL at CLIO, and in the $\mathrm{X}-\mathrm{H}(\mathrm{X}=\mathrm{C}, \mathrm{N}, \mathrm{O})$ stretching region (2900-3700 $\mathrm{cm}^{-1}$ ), using a tabletop IR OPO/OPA laser coupled to a modified Paul ion-trap.

In order to extract structural information, the IRMPD spectrum of $c i s-\left[\mathrm{Pt}\left(\mathrm{NH}_{3}\right)_{2}(\mathrm{G}) \mathrm{Cl}\right]^{+}$ions is compared with the calculated IR spectra of potential candidate geometries. The optimized structures for isomers corresponding to the $\operatorname{cis}$ - $\left[\mathrm{Pt}\left(\mathrm{NH}_{3}\right)_{2}(\mathrm{G}) \mathrm{Cl}\right]^{+}$general formula have been obtained by performing B3LYP/6-311G** calculations and are presented in Figure 2 (all the structures obtained in the present work are gathered in Figures S8 and S9 of the supporting information).

Guanine has three possible binding sites with the transition metal, the two nitrogen atoms $\mathrm{N} 3$ and N7, and the carbonyl oxygen atom (O6). ${ }^{52}$ Insights into the structural features of cisplatin interaction with guanine have been obtained in recent theoretical work. The N7 position of guanine was identified as the preferred platination target. ${ }^{53}$ The optimized geometries of cis- $\left[\mathrm{Pt}\left(\mathrm{NH}_{3}\right)_{2}(\mathrm{G}) \mathrm{Cl}\right]^{+}$presented in Figure 2 illustrate the three different binding sites of guanine. Binding to N7 gives rise to two conformers, as also illustrated recently, ${ }^{53}$ named PtGN7-1, where one hydrogen atom of an ammonia ligand interacts through a hydrogen bond with the carbonyl oxygen at the C6 position, and PtGN7-2 where the plane defined by the metal in its square planar coordination is perpendicular to the guanine plane. In fact the latter structure was actually a transition state at the B3LYP/6$31 \mathrm{G}^{* *}$ level (one negative eigenvalue). ${ }^{53}$ A similar result is obtained with the present level 
of calculation. Without any constraint, PtGN7-2 spontaneously evolves towards PtGN7-1. The coordination to O6 yields also two different conformers differing by the orientation of the $\left(\mathrm{NH}_{3}\right)_{2} \mathrm{Pt}(\mathrm{Cl})$ group with respect to the guanine ligand. In the first one, PtGO-1, a weak hydrogen bond is found between the hydrogen in N1 and the chloride ligand. In the second one, PtGO-2, a hydrogen bond is established between one hydrogen of an ammonia ligand and N7. In another isomer given in Figure 2, PtGN3, $\left(\mathrm{NH}_{3}\right)_{2} \mathrm{Pt}(\mathrm{Cl})$ is bound to N3. As shown by the relative free energies at $298 \mathrm{~K}$ reported in Figure 2, the global minimum corresponds to the PtGN7-1 complex. The preferred binding site of guanine is N7, yielding a structure that is stabilized by a strong hydrogen bond. When this hydrogen bond is not allowed, the ensuing conformer PtGN7-2 is only slightly more stable that the O-coordinated structures (PtGO-1 and PtGO-2). Globally, the two latter structures are less stable than PtGN7-1 by more than $40 \mathrm{~kJ} \mathrm{~mol}^{-1}$.

Finally, the platination onto the N3 position yields the least stable isomer, placed about 94 $\mathrm{kJ} \mathrm{mol}^{-1}$ above PtGN7-1. Examination of PtGN3 indicates that the guanine moiety is no longer planar. Consequently, coordination to the N3 atom induces an important distortion of the aromatic ring from planarity that destroys much of the resonance delocalization and is associated to a high-energy species.

In the FT-ICR mass spectrometer, it was possible to isolate the whole isotopic cluster corresponding to the $\operatorname{cis}$ - $\left[\mathrm{Pt}\left(\mathrm{NH}_{3}\right)_{2}(\mathrm{G}) \mathrm{Cl}\right]^{+}$complex at $\mathrm{m} / \mathrm{z}$ 414-418, submitting it to the IRMPD experiment. The fragmentation of $c i s-\left[\mathrm{Pt}\left(\mathrm{NH}_{3}\right)_{2}(\mathrm{G}) \mathrm{Cl}\right]^{+}$upon irradiation by IR photons in resonance with an active vibrational mode in the fingerprint region yields the same fragment ions as previously observed in the CID experiments, that is loss of one $\mathrm{NH}_{3}$ (cluster at $m / z, 397-401$ ), loss of two ammonia molecules (cluster at $m / z$ 380-384) and loss of two $\mathrm{NH}_{3}$ and $\mathrm{CO}$ (cluster at $\left.\mathrm{m} / z, 352-356\right)$. On the other hand, protonated guanine $(\mathrm{m} / \mathrm{z} 152)$ is not detected as photofragmentation product (Figure S4 of the supporting information). In 
the X-H stretching region $\left(2900-3700 \mathrm{~cm}^{-1}\right)$ the only photofragment observed in the IRMPD process is $\left[\mathrm{Pt}\left(\mathrm{NH}_{3}\right)(\mathrm{G}) \mathrm{Cl}\right]^{+}$(cluster at $m / z$ 397-401).

The IRMPD spectrum of cis- $\left[\mathrm{Pt}\left(\mathrm{NH}_{3}\right)_{2}(\mathrm{G}) \mathrm{Cl}\right]^{+}$in the $950-1900 \mathrm{~cm}^{-1}$ range is plotted in Figure $3 a$ together with the IR spectra calculated for the stable species presented in Figure 2. The experimental spectrum of $c i s-\left[\mathrm{Pt}\left(\mathrm{NH}_{3}\right)_{2}(\mathrm{G}) \mathrm{Cl}\right]^{+}$(Figure 3a) shows four pronounced features at 1289, 15971637 and $1718 \mathrm{~cm}^{-1}$ and other weaker bands appear at 1119, 1178, $1213,1330,1350,1428,1488$ and $1536 \mathrm{~cm}^{-1}$.

The main features in the experimental spectrum are nicely matched by the computed spectrum of the isomer PtGN7-1. Relying on the typically good agreement between the IRMPD spectrum and the linear IR spectrum of the sampled species obtained by DFT calculations, the vibrational modes of $c i s-\left[\mathrm{Pt}\left(\mathrm{NH}_{3}\right)_{2}(\mathrm{G}) \mathrm{Cl}\right]^{+}$can be assigned as described in Table S2 where the experimental IRMPD features are listed together with the IR bands calculated for the most stable isomer PtGN7-1. The IR bands calculated for other isomers together with the associated vibrational modes are listed in Tables S3-S5 in the supporting information.

The IRMPD feature at $1289 \mathrm{~cm}^{-1}$ is particularly broad and presents two shoulders at c.a. 1330 and $1350 \mathrm{~cm}^{-1}$. This signal comprises the umbrella bending modes of the two $\mathrm{NH}_{3}$ ligands. Interestingly, the umbrella mode for the ammonia ligand involved in H-bonding with the carbonyl oxygen in PtGN7-1 (denoted $\mathrm{NH}_{3}$ while the other ammonia is called $\mathrm{N}^{\prime} \mathrm{H}_{3}$ ) is calculated at $1318 \mathrm{~cm}^{-1}$, which may account for the shoulder observed experimentally at $1330 \mathrm{~cm}^{-1}$. The umbrella motion of the $\mathrm{N}^{\prime} \mathrm{H}_{3}$ ligand, trans to $\mathrm{G}$, presents a value, at $1301 \mathrm{~cm}^{-1}$. Finally, the shoulder at $1350 \mathrm{~cm}^{-1}$ on the high frequency side of the IRMPD band at $1289 \mathrm{~cm}^{-1}$ can be assigned to the in-plane bending of $\mathrm{H}-\mathrm{N} 1$.

The three strong bands at 1597,1637 and $1718 \mathrm{~cm}^{-1}$ are associated to the $\mathrm{NH}_{2}$ scissoring, the $\mathrm{H}_{2} \mathrm{~N}-\mathrm{C} 2$ stretching and the $\mathrm{C} 6=\mathrm{O}$ stretching modes calculated at 1597, 1637 and 1706 
$\mathrm{cm}^{-1}$ respectively. It is important to note that the $\mathrm{C}=\mathrm{O}$ stretching is red-shifted with respect to an unperturbed $\mathrm{C}=\mathrm{O}$ stretching vibration expected at ca. $1810 \mathrm{~cm}^{-1}$ as observed in isomer PtGN3. This effect can be explained by the formation of a Hydrogen bond that weakens the double bond character, and also by the proximity of the platinum ion. Note that the direct binding of the platinum ion to the $\mathrm{O} 6$ center further reduces the double bond character of $\mathrm{C} 6=\mathrm{O}$, and in fact its absorption is red-shifted to $1656 \mathrm{~cm}^{-1}$ (PtGO-1 structure, Table S4). Conversely, the $\mathrm{H}_{2} \mathrm{~N}-\mathrm{C} 2$ stretching mode is blue-shifted due to the partial double-bond character of the N-C2 bond, as attested by the $\mathrm{sp}^{2}$ hybridization of the $\mathrm{NH}_{2}$ group. The other minor absorptions can be assigned to vibrational modes of the purine ring and are reported in detail in Table S2. As a further remark on the IRMPD spectrum of cis-[Pt( $\left.\left(\mathrm{NH}_{3}\right)_{2}(\mathrm{G}) \mathrm{Cl}\right]^{+}$ in the fingerprint region, one may note that recording the spectrum with an attenuated beam (thus reducing saturation effects) brings the relative band intensities in better agreement with the calculated IR spectrum of PtGN7-1.

Examination of Figure 3 shows that the IR signatures of PtGO-1 or PtGO-2 forms are also globally consistent with the experimental spectrum, and consequently, cannot be rigorously excluded. However, these two structures are significantly less stable than PtGN7 in the gas phase. In addition, PCM calculations were also carried out onto these complexes in order to get some insight about the effect of the solvent. These calculations show that the energy gap between these three forms should be further increased in water, which is consistent with the prominent formation of PtGN7 during the ESI process, if one considers that the ion population will reflect the Boltzmann equilibrium distribution in water.

The $c i s-\left[\mathrm{Pt}\left(\mathrm{NH}_{3}\right)_{2}(\mathrm{G}) \mathrm{Cl}\right]^{+}$ions have also been investigated in the region from 2900 to 3700 $\mathrm{cm}^{-1}$. As shown in the lower panel of Figure 4, cis- $\left[\mathrm{Pt}\left(\mathrm{NH}_{3}\right)_{2}(\mathrm{G}) \mathrm{Cl}\right]^{+}$presents numerous absorptions, the four major ones being observed at $3417,3437,3453$ and $3474 \mathrm{~cm}^{-1}$. 
Other weaker but still significant features are detected at 3054, 3153, 3340, 3387, 3537 and $3559 \mathrm{~cm}^{-1}$. Once again, on comparing with the calculated IR spectra convoluted with a Gaussian profile of $5 \mathrm{~cm}^{-1}$ (FWHM) reported in Figure 4b-e, one finds a generally good agreement between the IRMPD spectrum of cis- $\left[\mathrm{Pt}\left(\mathrm{NH}_{3}\right)_{2}(\mathrm{G}) \mathrm{Cl}\right]^{+}$and the IR spectrum of isomer PtGN7-1. The main feature at $3474 \mathrm{~cm}^{-1}$ can be assigned to the N9-H stretching mode expected at $3470 \mathrm{~cm}^{-1}$. The absorption at $3417 \mathrm{~cm}^{-1}$ corresponds to the $\mathrm{N} 1-\mathrm{H}$ stretching mode calculated at $3421 \mathrm{~cm}^{-1}$. The two bands at $3453 \mathrm{~cm}^{-1}$ and $3559 \mathrm{~cm}^{-1}$ are consistent with the symmetric and antisymmetric stretching modes of $\mathrm{NH}_{2}$ expected at 3451 and $3567 \mathrm{~cm}^{-1}$, respectively, for PtGN7-1. The two bands at 3340 and $3387 \mathrm{~cm}^{-1}$ are due to antisymmetric stretching modes of the $\mathrm{NH}_{3}$ ligands. The first one comprises two absorptions calculated at 3345 and $3353 \mathrm{~cm}^{-1}$ and the second one is a convolution of modes active at 3393 and $3401 \mathrm{~cm}^{-1}$. The feature at $3153 \mathrm{~cm}^{-1}$ is compatible with the $\mathrm{C} 8-\mathrm{H}$ stretching mode expected at $3148 \mathrm{~cm}^{-1}$. The experimental IRMPD spectrum of $c i s-\left[\mathrm{Pt}\left(\mathrm{NH}_{3}\right)_{2}(\mathrm{G}) \mathrm{Cl}\right]^{+}$shows a broad absorption around $3054 \mathrm{~cm}^{-1}$ that may be assigned to the $\mathrm{NH}$ stretching of the N-H bond involved in hydrogen bonding with the carbonyl oxygen of guanine, calculated at 3038 $\mathrm{cm}^{-1}$. Although the calculated intensity for this stretching mode involving hydrogen-bonding is high, the experimental band is rather weak. Previously, such simultaneous red-shifts and broadening effects of stretching vibrations of $\mathrm{X}-\mathrm{H}(\mathrm{X}=\mathrm{N}, \mathrm{O})$ groups involved in a hydrogen bond have been observed for water solvated clusters ${ }^{54}$, solvated amino acids ${ }^{55}$ or nucleobases. ${ }^{56,57}$, and lactic ester derivatives. ${ }^{58}$ One possible explanation may lie in the anharmonicity of this mode and the ensuing low IRMPD efficiency. However the presence of these two latter features is remarkable. To our knowledge this is one of the first example of NH vibration involved in hydrogen bonding revealed by IRMPD spectroscopy using an OPO/OPA laser, in the absence of a loosely bound tag such as a solvating water molecule. ${ }^{54}$ It is also difficult to observe $\mathrm{C}-\mathrm{H}$ stretching modes for covalently bonded species with the 
present experimental apparatus. Typically, these modes are weakly active and at the same time the laser power at wavenumbers lower than $3100 \mathrm{~cm}^{-1}$ is appreciably decreasing. It may be noted that the experimental spectrum of cis- $\left[\mathrm{Pt}\left(\mathrm{NH}_{3}\right)_{2}(\mathrm{G}) \mathrm{Cl}\right]^{+}$shows two features that do not find a counterpart in the calculated IR spectrum of isomer PtGN7-1, namely the bands at 3437 and $3537 \mathrm{~cm}^{-1}$. These signals can be compared with two absorptions bands computed for the PtGN7-2 conformer, at 3435 and $3553 \mathrm{~cm}^{-1}$, respectively, corresponding to the symmetric and antisymmetric stretching mode of $\mathrm{NH}_{2}$ as reported in Figure $\mathrm{S} 5$ on the Supporting Information. Considering the high relative free energy of PtGN7-2 with respect to PtGN7-1 (higher than $42 \mathrm{~kJ} \mathrm{~mol}^{-1}$ ) and given the fact that this structure is actually a transition state on the potential energy surface, it is somewhat difficult to conceive the presence of the PtGN7-2 in any significant amount from the ESI process. More probably, these two relatively minor absorptions may arise from a conformer that has been missed in the conformational survey. Whatever the right explanation could be, the observed features appear consistent with an isomer characterized by $c i s-\left[\mathrm{Pt}\left(\mathrm{NH}_{3}\right)_{2} \mathrm{Cl}\right]^{+}$binding to guanine in N7 position.

\subsection{IRMPD spectroscopy of $c i s-\left[\mathrm{Pt}\left(\mathrm{NH}_{3}\right)_{2}(\mathrm{~A}) \mathrm{Cl}\right]^{+}$complex}

The last issue addressed in this work regards the structure of the $\operatorname{cis}$ - $\left[\mathrm{Pt}\left(\mathrm{NH}_{3}\right)_{2}(\mathrm{~A}) \mathrm{Cl}\right]^{+}$ complex generated in the water solution. Contrary to guanine, the three possible binding sites of adenine, namely N1, N3 and N7, show a quite similar affinity for the platinum moiety. The calculated binding affinity order for $\left[\mathrm{Pt}\left(\mathrm{NH}_{3}\right)_{3}\right]^{2+}$ was $\mathrm{N} 3\left(368.2 \mathrm{~kJ} \mathrm{~mol}^{-1}\right) \geq \mathrm{N} 1$ $\left(364.0 \mathrm{~kJ} \mathrm{~mol}^{-1}\right)>\mathrm{N} 7\left(338.9 \mathrm{~kJ} \mathrm{~mol}^{-1}\right) .{ }^{52}$ In DNA, cisplatin binds the adenine residue especially onto N7 and N1 positions. However, dealing with the nucleobase alone, the three positions are all potentially available for the cisplatin interaction. Furthermore, previous studies have demonstrated that adenine can tautomerize in water and polar solvents. ${ }^{59,60}$ 
NMR measurements in water have established the coexistence of two amino tautomers of adenine, namely the N9-H tautomer (so-called native adenine, predominant by a factor of ca. 4) and the N7-H structure. ${ }^{61}$ The presence of the N3-H form, though in only minor amount, has been detected exclusively in DMSO solvent. ${ }^{59}$ For this reason, in addition to the conventional binding sites of canonical adenine, complexes of $\left(\mathrm{NH}_{3}\right)_{2} \mathrm{Pt}(\mathrm{Cl})^{+}$with the N7-H tautomers have also been considered as potential candidates for the cis$\left[\mathrm{Pt}\left(\mathrm{NH}_{3}\right)_{2}(\mathrm{~A}) \mathrm{Cl}\right]^{+}$complex obtained in aqueous solution. Figure 5 displays the optimized structures of the most stable conformer for plausible $c i s-\left[\mathrm{Pt}\left(\mathrm{NH}_{3}\right)_{2}(\mathrm{~A}) \mathrm{Cl}\right]^{+}$isomers as obtained at the B3LYP/6-311G** level.

The PtAN3 structure illustrates the most stable conformer obtained by the interaction of the $\left(\mathrm{NH}_{3}\right)_{2} \mathrm{PtCl}^{+}$unit with the $\mathrm{N} 3$ position of native adenine. The chloride ion is pointing towards the hydrogen atom in N9. The distance between the two atoms $(2,723 \AA)$ is too large to allow proper $\mathrm{H}$-bonding, however it may provide stabilization by an electrostatic effect. The binding to N1 and N7 positions of adenine in the native form yields structures PtAN1 and PtAN7, respectively (Figure 5). In the N7-H amino tautomer of adenine, binding to N3 yields PtAN3N7t also shown in Figure 5. In this structure, a hydrogen bond is established between a hydrogen of an ammonia ligand and N9. The PtAN9N7t form, obtained by the coordination of $\mathrm{Pt}\left(\mathrm{NH}_{3}\right)_{2} \mathrm{Cl}^{+}$to $\mathrm{N} 9$ of the $\mathrm{N} 7-\mathrm{H}$ tautomer, also allows hydrogen bonding between a hydrogen of an ammonia ligand and N3.

Focusing on the three isomers of the cis-[Pt( $\left.\left.\mathrm{NH}_{3}\right)_{2}(\mathrm{~A}) \mathrm{Cl}\right]^{+}$complexes involving native adenine, binding to $\mathrm{N} 3$ gives rise to the lowest energy isomer. In agreement with previous calculations, ${ }^{52}$ PtAN1 is only $5.3 \mathrm{~kJ} \mathrm{~mol}^{-1}$ less stable than PtAN3 and the coordination to N7 (PtAN7), is less favoured by $13.3 \mathrm{~kJ} \mathrm{~mol}^{-1}$. Unexpectedly, the two structures of cis$\left[\mathrm{Pt}\left(\mathrm{NH}_{3}\right)_{2}(\mathrm{~A}) \mathrm{Cl}\right]^{+}$involving tautomer $\mathrm{N} 7-\mathrm{H}$ are lower in energy with respect to PtAN3. This result may appear surprising because native adenine is calculated to be the most stable 
tautomer. $^{59,62}$ A probable explanation lies in the presence of a hydrogen bond in both PtAN3N7t and PtAN9N7t complexes, providing additional stabilization to these species. The lowest energy isomer is thus PtAN9N7t, $13.7 \mathrm{~kJ} \mathrm{~mol}^{-1}$ more stable than PtAN3. On the other hand, PCM calculations suggest PtAN3 as the most stable structure in solution, the energy difference between the various forms being strongly reduced (Figure 5).

As in the case of $c i s-\left[\mathrm{Pt}\left(\mathrm{NH}_{3}\right)_{2}(\mathrm{G}) \mathrm{Cl}\right]^{+}$, the whole isotopic cluster corresponding to the cis$\left[\mathrm{Pt}\left(\mathrm{NH}_{3}\right)_{2}(\mathrm{~A}) \mathrm{Cl}\right]^{+}$complex at $\mathrm{m} / z$ 398-404 was isolated prior to starting the IRMPD experiment. The photofragmentation efficiency observed for cis- $\left[\mathrm{Pt}\left(\mathrm{NH}_{3}\right)_{2}(\mathrm{~A}) \mathrm{Cl}\right]^{+}$was lower than in the case of cis-[Pt( $\left.\left(\mathrm{NH}_{3}\right)_{2}(\mathrm{G}) \mathrm{Cl}\right]^{+}$in both spectroscopic regions investigated (resulting in smaller $\mathrm{R}$ values).

In the fingerprint region there are only four photofragment ions observed, as reported in Figure S6 in the supporting material. The principal fragment ion is the one from loss of one $\mathrm{NH}_{3}$ (cluster at $\mathrm{m} / \mathrm{z}, 381-387$ ) and a second abundant one is the protonated adenine at $\mathrm{m} / \mathrm{z}$ 136. A less abundant photofragment is due to loss of one ammonia plus a hydrogen chloride molecule (cluster at $\mathrm{m} / \mathrm{z} 345-347$ ). This ion tends to add a molecule of water, present as unavoidable contaminant in the Paul trap, (cluster at $m / z$ 365-367). The same ionic products are observed for photodissociation in the X-H stretching region $\left(2900-3700 \mathrm{~cm}^{-1}\right)$. It should be noted that, in contrast with the behavior displayed by cis- $\left[\mathrm{Pt}\left(\mathrm{NH}_{3}\right)_{2}(\mathrm{G}) \mathrm{Cl}\right]^{+}$, protonated adenine is always present as photofragment. This fact is in line with a stronger binding of guanine with respect to adenine in platinum complexes.

The IRMPD spectrum of cis-[Pt( $\left.\left(\mathrm{NH}_{3}\right)_{2}(\mathrm{~A}) \mathrm{Cl}\right]^{+}$recorded in the $1000-1900 \mathrm{~cm}^{-1}$ spectral range is reported in the lower panel of Figure 6, together with the calculated IR spectra of the species shown in Figure 5.

Even using a longer irradiation time (1 sec instead of $250 \mathrm{~ms}$ ), the photofragmentation process is considerably less extensive than that observed for cis- $\left[\mathrm{Pt}\left(\mathrm{NH}_{3}\right)_{2}(\mathrm{G}) \mathrm{Cl}\right]^{+}$. Three 
main features are present in the spectrum of $c i s-\left[\mathrm{Pt}\left(\mathrm{NH}_{3}\right)_{2}(\mathrm{~A}) \mathrm{Cl}\right]^{+}$at 1300,1430 and 1658 $\mathrm{cm}^{-1}$, respectively. The latter absorption is preceded by a shoulder at $1610 \mathrm{~cm}^{-1}$. Other weaker bands are found at 1120, 1208, 1256, 1361 and $1494 \mathrm{~cm}^{-1}$. Apparently, all the calculated spectra displayed in Figure 6 seem to be very similar to each other and well related to the experimental one. However, some minor differences in the calculated spectra may allow an insight about the sampled ion population. At first sight, one may exclude the presence of PtAN7, in the cis-[Pt( $\left.\left(\mathrm{NH}_{3}\right)_{2}(\mathrm{~A}) \mathrm{Cl}\right]^{+}$experimental ion population. The band calculated at about $1602 \mathrm{~cm}^{-1}$, combining two highly active vibrational modes at 1594 and $1616 \mathrm{~cm}^{-1}$, is notably shifted with respect to the experimental one found at $1658 \mathrm{~cm}^{-1}$. In contrast, all other four species taken in consideration present a strong feature at nearly constant frequency, namely at 1641, 1638, 1639 and $1642 \mathrm{~cm}^{-1}$ for PtAN3N7t, PtAN9N7t, PtAN1 and PtAN3, respectively. As another criterion helping to assign the proper structure, one may consider the gap between this feature and the band preceding it. In the two isomers of tautomer N7-H, the difference in the band position is $76 \mathrm{~cm}^{-1}$ for PtAN3N7t (at 1565 and $1641 \mathrm{~cm}^{-1}$ ) and $67 \mathrm{~cm}^{-1}$ for PtAN9N7t (the two bands are predicted at 1571 and $1638 \mathrm{~cm}^{-1}$ ). These two values are significantly greater than the gap observed experimentally $\left(48 \mathrm{~cm}^{-1}\right)$, rather disproving the presence of these two species in relevant amount in the sampled cis$\left[\mathrm{Pt}\left(\mathrm{NH}_{3}\right)_{2}(\mathrm{~A}) \mathrm{Cl}\right]^{+}$ions. The calculated spectrum of PtAN3 gives the best fit with the experimental spectrum. The gap between the two absorptions in the higher frequency region of the mid-IR spectrum is $55 \mathrm{~cm}^{-1}$, in quite good agreement with the experimental value of $48 \mathrm{~cm}^{-1}$. The band at $1361 \mathrm{~cm}^{-1}$ finds a counterpart in the calculated mode at ca. $1355 \mathrm{~cm}^{-1}$, associated with the convolution of two bands at 1341 and $1362 \mathrm{~cm}^{-1}$. There is also a good agreement with other features of the spectrum. Only two experimental IRMPD bands do not find a counterpart in the calculated spectrum of isomer PtAN3, the small absorption at 1494 $\mathrm{cm}^{-1}$, as well as the band at $1208 \mathrm{~cm}^{-1}$, which, however, can be both observed in the 
calculated spectrum of isomer PtAN1, at 1488 and $1206 \mathrm{~cm}^{-1}$, respectively. PtAN1 shows a separation of $45 \mathrm{~cm}^{-1}$ in the position of the two bands at around $1600 \mathrm{~cm}^{-1}$, in accord with the experimental spectrum. These findings suggest that the ionic adduct cis$\left[\mathrm{Pt}\left(\mathrm{NH}_{3}\right)_{2}(\mathrm{~A}) \mathrm{Cl}\right]^{+}$under examination would be a mixture of both isomers PtAN3 and PtAN1. In addition, several argument are in favor of a minor, if any, contribution of complexes containing N7-H tautomers. First of all, as previously reported, ${ }^{59,60}$ native adenine is the major species in water solution, and PCM calculations suggest that the most stable cis- $\left[\mathrm{Pt}\left(\mathrm{NH}_{3}\right)_{2}(\mathrm{~A}) \mathrm{Cl}\right]^{+}$complex (PtAN3), involves native adenine. Secondly, due to the poor solubility of adenine, an aqueous solution of 5'-dAMP rather than of adenine was used in the present study to generate $c i s-\left[\mathrm{Pt}\left(\mathrm{NH}_{3}\right)_{2}(\mathrm{~A}) \mathrm{Cl}\right]^{+}$. Reported NMR measurements of AMP in water solution have found that this species, in contrast with adenine, does not tautomerize. ${ }^{59}$ One may therefore argue that in solution cis- $\left[\mathrm{Pt}\left(\mathrm{NH}_{3}\right)_{2}\left(\mathrm{H}_{2} \mathrm{O}\right) \mathrm{Cl}\right]^{+}$is reacting with 5'-dAMP and in the event of ion transfer to the gas phase during the electrospray process, direct $\mathrm{N}$-glycosidic bond cleavage occurs, yielding native adenine-containing cis$\left[\mathrm{Pt}\left(\mathrm{NH}_{3}\right)_{2}(\mathrm{~A}) \mathrm{Cl}\right]^{+}$ion.

With these considerations in mind, the vibrational modes of $c i s-\left[\mathrm{Pt}\left(\mathrm{NH}_{3}\right)_{2}(\mathrm{~A}) \mathrm{Cl}\right]^{+}$can be in a first attempt assigned as described in Table S6, where the experimental IRMPD features are listed together with the IR bands calculated for PtAN3. Focusing on the main absorptions, the experimental band at $1300 \mathrm{~cm}^{-1}$ can be assigned to the umbrella mode of the ammonia ligands calculated at 1295 and $1310 \mathrm{~cm}^{-1}$. The principal feature at $1658 \mathrm{~cm}^{-1}$ can be related to the combination of two vibrational modes, namely the $\mathrm{NH}_{2}$ scissoring and the $\mathrm{C} 6-\mathrm{NH}_{2}$ stretching, expected at $1642 \mathrm{~cm}^{-1}$. Finally, the shoulder at $1610 \mathrm{~cm}^{-1}$ may correspond to $\mathrm{NH}_{2}$ scissoring combined with ring deformation modes, computed at 1582 and $1588 \mathrm{~cm}^{-1}$, respectively. 
To complete this study, the IRMPD spectrum of cis-[Pt( $\left.\left(\mathrm{NH}_{3}\right)_{2}(\mathrm{~A}) \mathrm{Cl}\right]^{+}$has also been recorded in the $3000-3700 \mathrm{~cm}^{-1}$ spectral range, using an irradiation time of $2 \mathrm{~s}$ and the full laser power in order to maximize the photofragmentation yield. As reported in the lower panel of Figure 7, the experimental IRMPD spectrum of $c i s-\left[\mathrm{Pt}\left(\mathrm{NH}_{3}\right)_{2}(\mathrm{~A}) \mathrm{Cl}\right]^{+}$presents three main absorptions at 3353, 3428 and $3477 \mathrm{~cm}^{-1}$ and two shoulders at 3375 and $3456 \mathrm{~cm}^{-1}$.

The spectrum is consistent with the presence of both PtAN3 and PtAN1 isomers in the sampled cis- $\left[\mathrm{Pt}\left(\mathrm{NH}_{3}\right)_{2}(\mathrm{~A}) \mathrm{Cl}\right]^{+}$ion population, although some calculated IR bands of expected lower activity are missing in the experimental spectrum. The main feature at 3428 $\mathrm{cm}^{-1}$ is in good agreement with the symmetric stretching of $\mathrm{NH}_{2}$ expected at $3430 \mathrm{~cm}^{-1}$ for PtAN3 isomer (Table 2). The large band at $3477 \mathrm{~cm}^{-1}$ can be assigned to a convolution of two vibrational modes of PtAN1 isomer, namely the N9-H stretching mode and the asymmetric stretching mode of $\mathrm{NH}_{2}$ calculated at 3469 and $3478 \mathrm{~cm}^{-1}$, respectively. The small hump at about $3456 \mathrm{~cm}^{-1}$ is compatible with the N9-H stretching mode of PtAN3 estimated at $3440 \mathrm{~cm}^{-1}$. The absorption at $3353 \mathrm{~cm}^{-1}$ with a large shoulder at around 3375 $\mathrm{cm}^{-1}$ corresponds to stretching modes of $\mathrm{NH}_{3}$ groups pertaining to both isomers, expected at 3353, 3379, 3386 and $3382 \mathrm{~cm}^{-1}$ for PtAN3 and 3352, 3372, 33743392 and $3396 \mathrm{~cm}^{-1}$ for PtAN1. Regrettably, the calculated band at $3553 \mathrm{~cm}^{-1}$, which corresponds to the asymmetric stretching mode of $\mathrm{NH}_{2}$ of PtAN3 isomer, is not observed in the experimental spectrum. This missing band is not easy to explain, however it may be noted that this mode is very weak also in the experimental spectrum of cis- $\left[\mathrm{Pt}\left(\mathrm{NH}_{3}\right)_{2}(\mathrm{G}) \mathrm{Cl}\right]^{+}$, which has a much better IRMPD response. Such a weak asymmetric $\mathrm{NH}_{2}$ stretch has already been observed for $\mathrm{Li}+/$ adenine/thymine complexes ${ }^{28,29}$ and protonated dimers of adenine. ${ }^{63}$

A further experiment has finally demonstrated that the two main absorptions at 3428 and $3477 \mathrm{~cm}^{-1}$ do not belong to a single structure, as it is the case for the calculated spectra of PtAN3N7t and PtAN9N7t. Two IRMPD spectra of $\operatorname{cis}\left[\mathrm{Pt}\left(\mathrm{NH}_{3}\right)_{2}(\mathrm{~A}) \mathrm{Cl}\right]^{+}$have been 
recorded on the same day, the first one using a "fresh" solution (Figure S7a), where cisplatin and 5'-dAMP had been allowed to react for $24 \mathrm{~h}$ before the analysis, and the second one using an "old "solution where the two substrates had been incubated for two week (Figure S7b). The result was revealing. The IRMPD spectrum of the "fresh" solution was identical to the one reported in Figure 7. The experimental spectrum of the "old" solution instead showed a noticeable reversal in the relative intensities of the two main peaks as reported in Figure S7. The band at $3428 \mathrm{~cm}^{-1}$ is now weaker and the feature at $3477 \mathrm{~cm}^{-1}$ becomes the principal absorption. In our opinion, this fact is evidence that the two main bands pertain to at least two isomers. In fact, with a single isomer present, the same IRMPD spectrum should be recorded with characteristic band positions and intensities. This is indeed the case for $c i s-\left[\mathrm{Pt}\left(\mathrm{NH}_{3}\right)_{2}(\mathrm{G}) \mathrm{Cl}\right]^{+}$complex, showing constantly high reproducibility in IRMPD spectra run on different solutions and different days. In the specific case of cis-[ $\left.\mathrm{Pt}\left(\mathrm{NH}_{3}\right)_{2}(\mathrm{~A}) \mathrm{Cl}\right]^{+}$, the inversion of the intensities of the two bands suggests a slow isomerization within the complex. Studying the mechanisms associated with this isomerization is beyond the scope of the present manuscript, and will be the subject of further investigation. Clearly, it is noteworthy to underline that all the other experiments reported in the present paper were done only with "fresh" solutions, and thus can be referred to the same ionic population.

Certainly, the presence of $\mathrm{N} 7-\mathrm{H}$ tautomeric forms for the cis- $\left[\mathrm{Pt}\left(\mathrm{NH}_{3}\right)_{2}(\mathrm{~A}) \mathrm{Cl}\right]^{+}$complex cannot be rigorously excluded, notably given their particular calculated stability both in solution and in the gas phase. As suggested by one of the referee, and as already nicely illustrated for peptides ${ }^{64}$, use of isotopic labeling with ${ }^{15} \mathrm{~N}$, selectively introduced onto N7 and N9 positions of 5'-dAMP, would provide useful information in order to definitely attribute the various $\mathrm{N}-\mathrm{H}$ stretches (red-shifts), and would address the presence of isomeric forms, and especially tautomers. According to our DFT calculations, red-shifts of about 8-9 
$\mathrm{cm}^{-1}$ should be observed for the N7-H and N9-H stretches. Unfortunately, these compounds are not easily available.

\section{Conclusions}

The aim of this study is to provide an accurate characterization of cis- $\left[\mathrm{Pt}\left(\mathrm{NH}_{3}\right)_{2}(\mathrm{G}) \mathrm{Cl}\right]^{+}$and cis- $\left[\mathrm{Pt}\left(\mathrm{NH}_{3}\right)_{2}(\mathrm{~A}) \mathrm{Cl}\right]^{+}$, models of the monofunctional adducts between cisplatin and the nucleobases of DNA, using IR spectroscopy of ions directly performed in the cell of a mass spectrometer. Both the IR characterization and the computational results point to a covalent structure for the cis- $\left[\mathrm{Pt}\left(\mathrm{NH}_{3}\right)_{2}(\mathrm{G}) \mathrm{Cl}\right]^{+}$where $\mathrm{Pt}$ is uniformly bound to the $\mathrm{N} 7$ atom of guanine. In particular, the feature found at $1718 \mathrm{~cm}^{-1}$ corresponding to the $\mathrm{C}=\mathrm{O}$ stretching, notably red-shifted with respect to an unperturbed $\mathrm{C}=\mathrm{O}$ stretching vibration, and the absorption at $3054 \mathrm{~cm}^{-1}$ pertaining the $\mathrm{N}-\mathrm{H}$ stretching of the $\mathrm{NH}_{3}$ molecule involved in hydrogen bonding with the carbonyl oxygen of guanine are clear proofs of the existence of a strong hydrogen bond between the carbonyl group at the C6 position of guanine and the $\mathrm{H}$ atom of one $\mathrm{NH}_{3}$ ligand of cisPt in the Pt-guanine complex.

The IRMPD spectra of $c i s-\left[\mathrm{Pt}\left(\mathrm{NH}_{3}\right)_{2}(\mathrm{~A}) \mathrm{Cl}\right]^{+}$are consistent with the presence of two major isomers, PtAN3 and PtAN1, where Pt is bound in the N3, and N1 positions of native adenine, respectively.

The preferred platinum coordination site on adenine seems to be N3, which is not observed in the cell because such site is located in the internal groove and not easily accessible at an intrastrand cross-linking. However, this feature may open the way towards new transplatin compounds with a conformation potentially allowing an intrastrand cross-link between the N7 position of guanine and N3 position of adenine.

\section{Acknowledgements}


The authors wish to thank the CLIO team (J. M. Ortega, C. Six, G. Perilhous, J. P. Berthet) as well as P. Maitre and V. Steinmetz for their support during the experiments. Financial support has been provided by the Italian MIUR (Prin project 2009W2W4YF_004) and by the European Union (project IC007-11 entitled 'The interaction of cisplatin with nucleic acids: an approach by IRMPD spectroscopy')

\section{Supporting Information Available}

Detailed experimental mass spectra, CID and IRMPD spectra of ions under examination; tables with experimental and computed vibrational bands; all computed structures for cis$\left[\mathrm{Pt}\left(\mathrm{NH}_{3}\right)_{2}(\mathrm{G}) \mathrm{Cl}\right]^{+}$and $c$ is $-\left[\mathrm{Pt}\left(\mathrm{NH}_{3}\right)_{2}(\mathrm{~A}) \mathrm{Cl}\right]^{+}$are gathered into a supporting information. This material is available free of charge via the Internet at http://pubs.acs.org/ 


\section{References}

(1) Platinum and Other Metal Coordination Compounds in Cancer Chemotherapy; Howell, S. B., Ed.; Plenum Press: New-York, 1996.

(2) Rosenberg, B.; Van Camp, L.; Krigas, T. Nature 1965, 205, 698.

(3) Rosenberg, B.; Vancamp, L.; Trosko, J. E.; Mansour, V. H. Nature 1969, 222, 385.

(4) Jamieson, E. R.; Lippard, S. J. Chem. Rev. 1999, 99, 2467.

(5) Boulikas, T.; Pantos, A.; Bellis, E.; Christofis, P. Cancer therapy 2007, 5, 537.

(6) Sherman, S. E.; Lippard, S. J. Chem. Rev. 1987, 87, 1153.

(7) Bancroft, D. P.; Lepre, C. A.; Lippard, S. J. J. Am. Chem. Soc. 1990, 112, 6860.

(8) Sherman, S. E.; Gibson, D.; Wang, A. H.; Lippard, S. J. Science 1985, 230, 412.

(9) Sherman, S. E.; Gibson, D.; Wang, A. H. J.; Lippard, S. J. J. Am. Chem. Soc. 1988, $110,7368$.

(10) Chiavarino, B.; Crestoni, M. E.; Fornarini, S.; Lemaire, J.; Maitre, P.; MacAleese, L. J. Am. Chem. Soc. 2006, 128, 12553.

(11) Chiavarino, B.; Crestoni, M. E.; Fornarini, S.; Dopfer, O.; Lemaire, J.; Maitre, P. J. Phys. Chem. A 2006, 110, 9352.

(12) Brodbelt, J. S.; Wilson, J. J. Mass Spectrom. Rev. 2009, 28, 390.

(13) Coletti, C.; Re, N.; Scuderi, D.; Maitre, P.; Chiavarino, B.; Fornarini, S.; Lanucara, F.; Sinha, R. K.; Crestoni, M. E. Phys. Chem. Chem. Phys. 2010, 12, 13455.

(14) Sinha, R. K.; Chiavarino, B.; Crestoni, M. E.; Scuderi, D.; Fornarini, S. Int. J. Mass Spectrom. 2011, 308, 209.

(15) Chiavarino, B.; Crestoni, M. E.; Dopfer, O.; Maitre, P.; Fornarini, S. Angew. Chem. Int. Ed. 2012, 51, 4947.

(16) Chiavarino, B.; Crestoni, M. E.; Fornarini, S.; Lanucara, F.; Lemaire, J.; Maitre, P.; Scuderi, D. Int. J. Mass Spectrom. 2008, 270, 111.

(17) Kapota, C.; Lemaire, J.; Maitre, P.; Ohanessian, G. J. Am. Chem. Soc. 2004, 126, 1836.

(18) Polfer, N. C.; Oomens, J.; Dunbar, R. C. Phys. Chem. Chem. Phys. 2006, 8, 2744.

(19) Dunbar, R. C.; Polfer, N. C.; Oomens, J. J. Am. Chem. Soc. 2007, 129, 14562.

(20) MacAleese, L.; Maitre, P. Mass Spectrom. Rev. 2007, 26, 583.

(21) Polfer, N. C.; Oomens, J.; Dunbar, R. C. ChemPhysChem 2008, 9, 579.

(22) Balaj, O. P.; Kapota, C.; Lemaire, J.; Ohanessian, G. Int. J. Mass Spectrom. 2008, 269,

(23) Bush, M. F.; Oomens, J.; Saykally, R. J.; Williams, E. R. J. Am. Chem. Soc. 2008, 130, 6463.

(24) Gillis, E. A. L.; Rajabi, K.; Fridgen, T. D. J. Phys. Chem. A 2009, 113, 824.

(25) Eyler, J. R. Mass Spectrom. Rev. 2009, 28, 448.

(26) Polfer, N. C.; Oomens, J. Mass Spectrom. Rev. 2009, 28, 468.

(27) Zocher, E.; Sigrist, R.; Chen, P. Inorg. Chem. 2007, 46, 11366.

(28) Gillis, E. A. L.; Fridgen, T. D. Int. J. Mass Spectrom. 2010, 297, 2.

(29) Rajabi, K.; Gillis, E. A. L.; Fridgen, T. D. J. Phys. Chem. A 2010, 114, 3449.

(30) Salpin, J. Y.; Guillaumont, S.; Ortiz, D.; Tortajada, J.; Maitre, P. Inorg. Chem. 2011, $50,7769$.

(31) Salpin, J. Y.; Gamiette, L.; Tortajada, J.; Besson, T.; Maitre, P. Int. J. Mass Spectrom. 2011, 304, 154.

(32) Chiavarino, B.; Crestoni, M. E.; Fornarini, S.; Taioli, S.; Mancini, I.; Tosi, P. J. Chem. Phys. 2012, 137, 024307.

(33) Schröder, D.; Schwarz, H.; Aliaga-Alcalde, N.; Neese, F. Eur. J. Inorg. Chem. 2007,

816.

(34) Schröder, D.; Semialjac, M.; Schwarz, H. Int. J. Mass Spectrom. 2004, 233, 103. 
(35) Chiavarino, B.; Crestoni, M. E.; Fornarini, S.; Lanucara, F.; Lemaire, J.; Maitre, P.; Scuderi, D. Chem. Eur. J. 2009, 15, 8185.

(36) Armentrout, P. B. Int. J. Mass Spectrom. 2003, 227, 289.

(37) Armentrout, P. B.; Kickel, B. L. In Organometallic Ion Chemistry; Freiser, B. S., Ed.; Kluwer Academic Publishers: Dordrecht, 1996.

(38) Milko, P.; Roithova, J.; Schroder, D.; Lemaire, J.; Schwarz, H.; Holthausen, M. C. Chem. Eur. J. 2008, 14, 4318.

(39) Bouchoux, G.; Salpin, J. Y.; Leblanc, D. Int. J. Mass Spectrom. Ion Processes 1996, $153,37$.

(40) Bakker, J. M.; Besson, T.; Lemaire, J.; Scuderi, D.; Maitre, P. J. Phys. Chem. A 2007, $111,13415$.

(41) Lemaire, J.; Boissel, P.; Heninger, M.; Mauclaire, G.; Bellec, G.; Mestdagh, H.; Simon, A.; Le Caer, S.; Ortega, J. M.; Glotin, F.; Maitre, P. Phys. Rev. Lett. 2002, 89, 273002.

(42) Prell, J. S.; O'Brien, J. T.; Williams, E. R. J. Am. Soc. Mass Spectrom. 2010, 21, 800.

(43) Lee, C.; Yang, W.; Parr, R. G. Physical Reviews B 1988, 37, 785.

(44) Becke, A. D. J. Chem. Phys. 1993, 98, 5648.

(45) Frisch, M. J.et al.; Gaussian03, Revision C.02. See Supporting Information for complete citation.

(46) Hay, P. J.; Wadt, W. R. J. Chem. Phys. 1985, 82, 270.

(47) Wadt, W. R.; Hay, P. J. J. Chem. Phys. 1985, 82, 284.

(48) Hay, P. J.; Wadt, W. R. J. Chem. Phys. 1985, 82, 299.

(49) Stevens, W. J.; Krauss, M.; Basch, H.; Jasien, P. G. Can. J. Chem. 1992, 70, 612.

(50) Franska, M.; Franski, R.; Schroeder, G.; Springer, A.; Beck, S.; Linscheid, M. Rapid Commun. Mass Spectrom. 2005, 19, 970.

(51) Hunter, E. P.; Lias, S. G. Proton Affinity Evaluation In NIST Chemistry WebBook; Linstrom, P. J., Mallard, W. G., Eds.; NIST Standard Reference Database Number 69; National Institute of Standards and Technology: Gaithersburg, MD (http://webbook.nist.gov), 2005.

(52) Basch, H.; Krauss, M.; Stevens, W. J.; Cohen, D. Inorg. Chem. 1986, 25, 684.

(53) Baik, M. H.; Friesner, R. A.; Lippard, S. J. J. Am. Chem. Soc. 2003, 125, 14082.

(54) Wang, Y. S.; Chang, H. C.; Jiang, J. C.; Lin, S. H.; Lee, Y. T.; Chang, H. C. J. Am. Chem. Soc. 1998, 120, 8777.

(55) Kamariotis, A.; Boyarkin, O. V.; Mercier, S. R.; Beck, R. D.; Bush, M. F.; Williams, E. R.; Rizzo, T. R. J. Am. Chem. Soc. 2006, 128, 905.

(56) Bakker, J. M.; Sinha, R. K.; Besson, T.; Brugnara, M.; Tosi, P.; Salpin, J. Y.; Maitre, P. J. Phys. Chem. A 2008, 112, 12393.

(57) Bakker, J. M.; Salpin, J. Y.; Maitre, P. Int. J. Mass Spectrom. 2009, 283, 214.

(58) Scuderi, D.; Le Barbu-Debus, K.; Zehnacker, A. Phys. Chem. Chem. Phys. 2011, 13, 17916.

(59) Laxer, A.; Major, D. T.; Gottlieb, H. E.; Fischer, B. J. Org. Chem. 2001, 66, 5463.

(60) Seckarova, P.; Marek, R.; Malinakova, K.; Kolehmainen, E.; Hockova, D.; Hocek, M.; Sklenar, V. Tetrahedron Lett. 2004, 45, 6259.

(61) Shugar, D.; Psoda, A. In Biophysics. Nucleic acids. Physical Data II. Theoretical Investigations; Saenger, W., Ed.; Springer: Berlin, 1990.

(62) Guerra, C. F.; Bickelhaupt, F. M.; Saha, S.; Wang, F. J. Phys. Chem. A 2006, 110, 4012.

(63) Rajabi, K.; Theel, K.; Gillis, E. A. L.; Beran, G.; Fridgen, T. D. The Journal of Physical Chemistry A 2009, 113, 8099.

(64) Stearns, J. A.; Seaiby, C.; Boyarkin, O. V.; Rizzo, T. R. Phys. Chem. Chem. Phys. 2009, 11, 125. 


\section{Table and Figure caption}

Figure 1. Relative abundances of the precursor ion and fragment ions as a function of the center of mass collision energy $\left(\mathrm{E}_{\mathrm{CM}}\right)$ during CID of mass-selected $\left.\boldsymbol{a}\right)\left[{ }^{195} \mathrm{Pt}\left(\mathrm{NH}_{3}\right)(\mathrm{G}){ }^{35} \mathrm{Cl}\right]^{+}$ $(m / z, 398), \boldsymbol{b})\left[{ }^{195} \mathrm{Pt}\left(\mathrm{NH}_{3}\right)(\mathrm{A})^{35} \mathrm{Cl}\right]^{+}(\mathrm{m} / \mathrm{z}, 382)$ and c) $\left[{ }^{195} \mathrm{Pt}(\mathrm{A})(\mathrm{G})(-\mathrm{H})\right]^{+}(\mathrm{m} / \mathrm{z} 480)$ ions. See text for details

Figure 2. Geometries and relative free energies $\left(\mathrm{kJ} \mathrm{mol}^{-1}\right.$, in parentheses) for represnentative cis-[Pt( $\left.\left(\mathrm{NH}_{3}\right)_{2}(\mathrm{G}) \mathrm{Cl}\right]^{+}$structures calculated at the B3LYP/6-311G** level. Distances are given in Angström. Relative free energies given in italic were obtained by using the Polarized Continuum Model (PCM) approach

Figure 3. a) Experimental IRMPD spectrum of cis-[Pt( $\left.\left(\mathrm{NH}_{3}\right)_{2}(\mathrm{G}) \mathrm{Cl}\right]^{+}$obtained with full (green) and attenuated (by a factor of two, red) laser power together with computed IR spectra of $b$ ) PtGN7-1 c) PTGO-1, $d$ ) PtGO-2 and $\boldsymbol{e}$ ) PtGN3, all calculated at the B3LYP/ $6-311 \mathrm{G}^{* *}$ level in the spectral range of $950-1900 \mathrm{~cm}^{-1}$.

Figure 4. a) Experimental IRMPD spectrum of cis-[Pt( $\left.\left(\mathrm{NH}_{3}\right)_{2}(\mathrm{G}) \mathrm{Cl}\right]^{+}$obtained with an irradiation time of 1 second (green) and 2 second (blue) respectively, together with computed IR spectra of $b$ ) PtGN7-1, c) PTGO-1, $d$ ) PtGO-2 and $\boldsymbol{e}$ ) PtGN3, all calculated at the B3LYP/ 6-311G** level in the spectral range of $2900-3700 \mathrm{~cm}^{-1}$.

Figure 5. Geometries and relative free energies $\left(\mathrm{kJ} \mathrm{mol}^{-1}\right.$, in parentheses) for representative cis- $\left[\mathrm{Pt}\left(\mathrm{NH}_{3}\right)_{2}(\mathrm{~A}) \mathrm{Cl}\right]^{+}$structures calculated at the B3LYP/6-311G** level. Distances are given in Angströms. Relative free energies given in italic were obtained by using the Polarized Continuum Model (PCM) approach

Figure 6. a) Experimental IRMPD spectrum of cis-[Pt( $\left.\left(\mathrm{NH}_{3}\right)_{2}(\mathrm{~A}) \mathrm{Cl}\right]^{+}$together with computed IR spectra of $b)$ PtAN3, c) PtAn1, d) PtAn7, e) PtAN9N7t and f) Ptan3N7t, all calculated at the B3LYP/ 6-311G** level, in the spectral range of $1000-1900 \mathrm{~cm}^{-1}$. Computed intensities are displayed between 0 and $1000 \mathrm{~km} / \mathrm{mol}$.

Figure 7. a) Experimental IRMPD spectrum of cis-[Pt( $\left.\left(\mathrm{NH}_{3}\right)_{2}(\mathrm{~A}) \mathrm{Cl}\right]^{+}$together with computed IR spectra of b) PtAN3, c) PtAn1, d) PtAn7, e) PtAn9N7t and f) PtAN3N7t, all calculated at the at the B3LYP/ 6-311G** level, in the spectral range of $3000-3700 \mathrm{~cm}^{-1}$. 

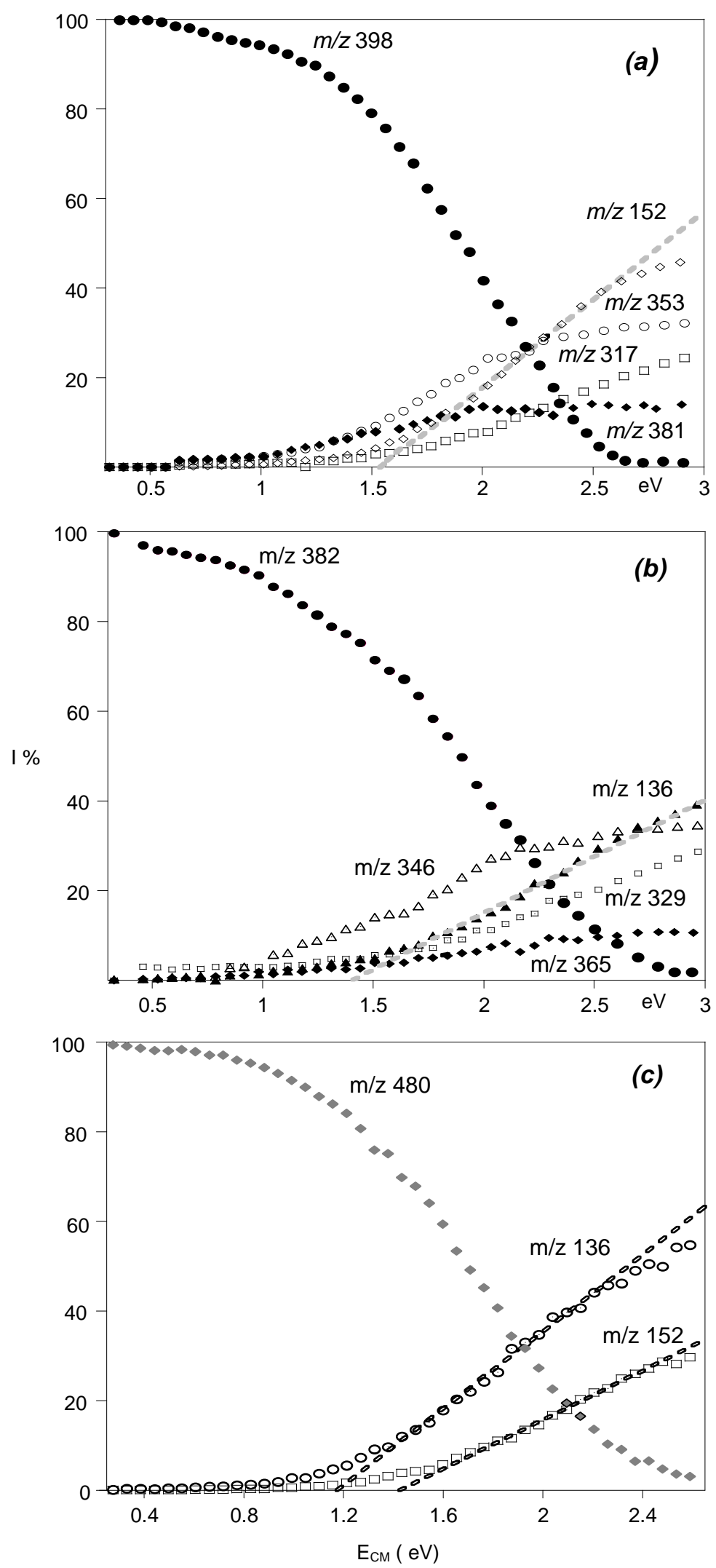

Figure 1. Relative abundances of the precursor ion and fragment ions as a function of the center of mass collision energy $\left(\mathrm{E}_{\mathrm{CM}}\right)$ during CID of mass-selected $\left.a\right)\left[{ }^{195} \mathrm{Pt}\left(\mathrm{NH}_{3}\right)(\mathrm{G})^{35} \mathrm{Cl}\right]^{+}$ $(m / z, 398), \boldsymbol{b})\left[{ }^{195} \mathrm{Pt}\left(\mathrm{NH}_{3}\right)(\mathrm{A})^{35} \mathrm{Cl}\right]^{+}(\mathrm{m} / \mathrm{z} 382)$ and $\left.\boldsymbol{c}\right)\left[{ }^{195} \mathrm{Pt}(\mathrm{A})(\mathrm{G})(-\mathrm{H})\right]^{+}(\mathrm{m} / \mathrm{z} 480)$ ions. See text for details 


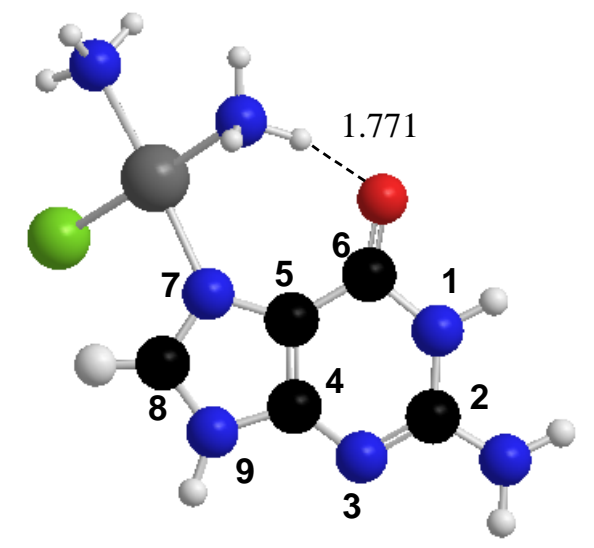

PtGN7-1 (0.0;0.0)

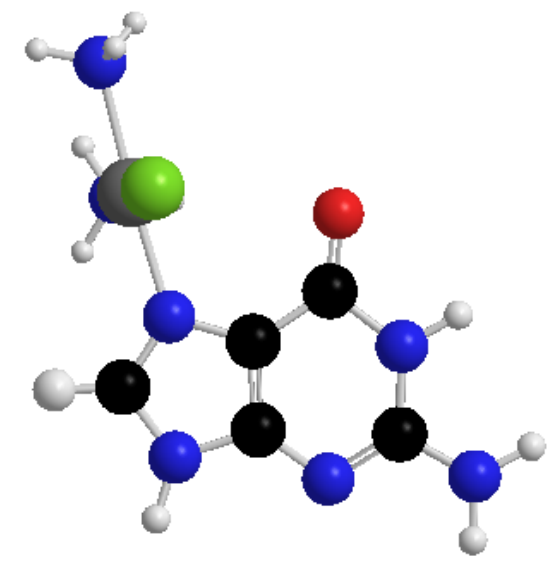

PtGN7-2 (+42.2; +23.9)

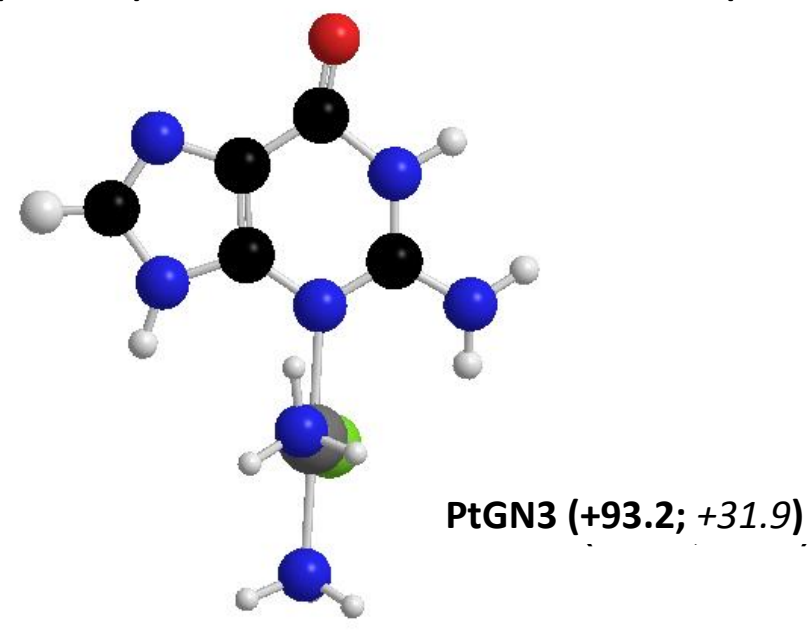

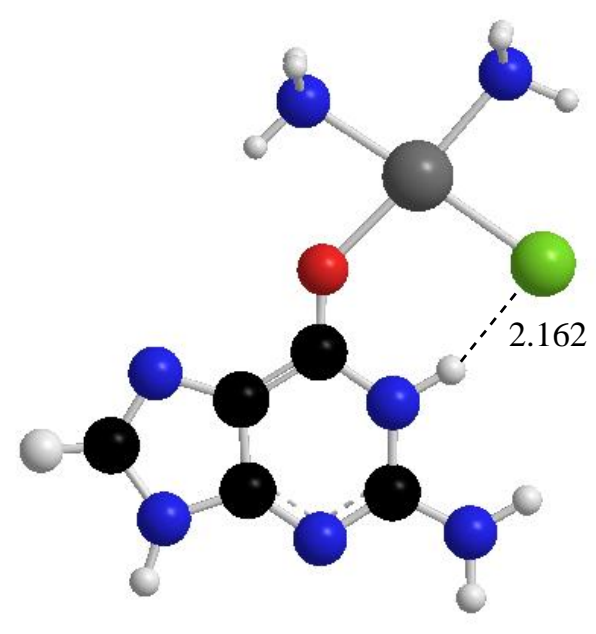

PtGO-1 (+47.2; +60.2)

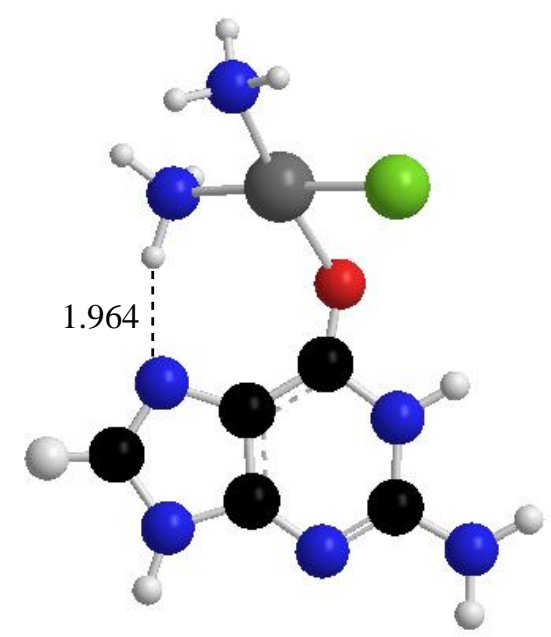

PtGO-2 (+56.6; +54.1)

Figure 2. Geometries and relative free energies $\left(\mathrm{kJ} \mathrm{mol}^{-1}\right.$, in parentheses) for representative cis- $\left[\mathrm{Pt}\left(\mathrm{NH}_{3}\right)_{2}(\mathrm{G}) \mathrm{Cl}\right]^{+}$structures calculated at the B3LYP/6-311G** level. Distances are given in Angströms. Relative free energies given in italic were obtained by using the Polarized Continuum Model (PCM) approach 


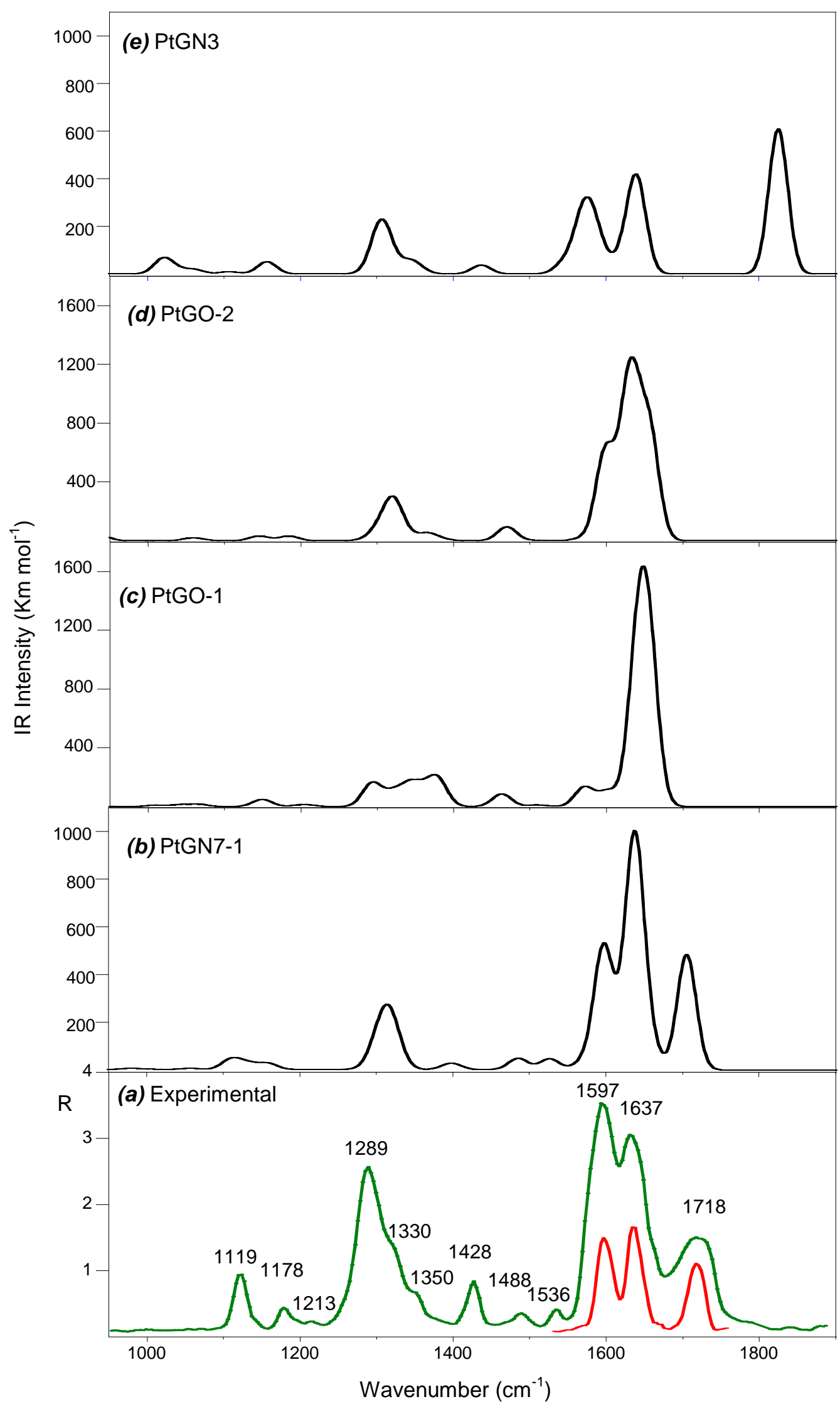

Figure 3. a) Experimental IRMPD spectrum of cis-[Pt( $\left.\left(\mathrm{NH}_{3}\right)_{2}(\mathrm{G}) \mathrm{Cl}\right]^{+}$obtained with full (green) and attenuated (by a factor of two, red) laser power together with computed IR spectra of $\boldsymbol{b})$ PtGN7-1 $\boldsymbol{c}$ ) PTGO-1, $\boldsymbol{d}$ ) PtGO-2 and $\boldsymbol{e}$ ) PtGN3, all calculated at the B3LYP/ 6-311G** level in the spectral range of $950-1900 \mathrm{~cm}^{-1}$. 


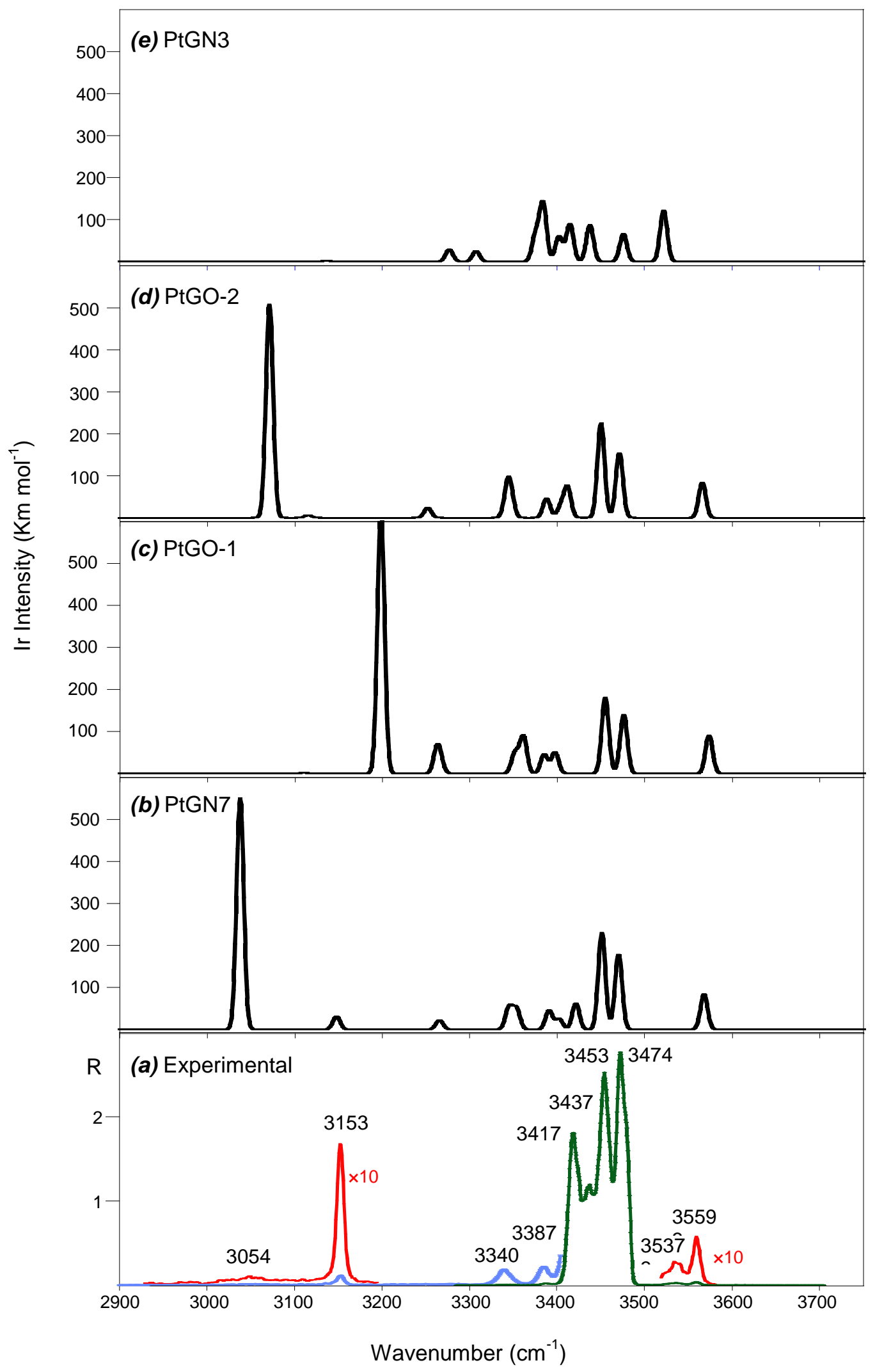

Figure 4. a) Experimental IRMPD spectrum of cis-[Pt( $\left.\left(\mathrm{NH}_{3}\right)_{2}(\mathrm{G}) \mathrm{Cl}\right]^{+}$obtained with an irradiation time of 1 second (green) and 2 second (blue) respectively, together with computed IR spectra of $b$ ) PtGN7-1, c) PTGO-1, $d$ ) PtGO-2 and $\boldsymbol{e}$ ) PtGN3, all calculated at the B3LYP/ 6-311G** level in the spectral range of $2900-3700 \mathrm{~cm}^{-1}$. 


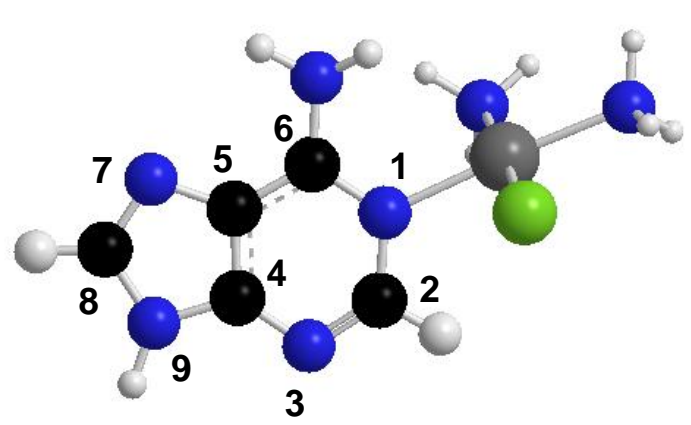

PtAN1 (+5.3; +4.1)

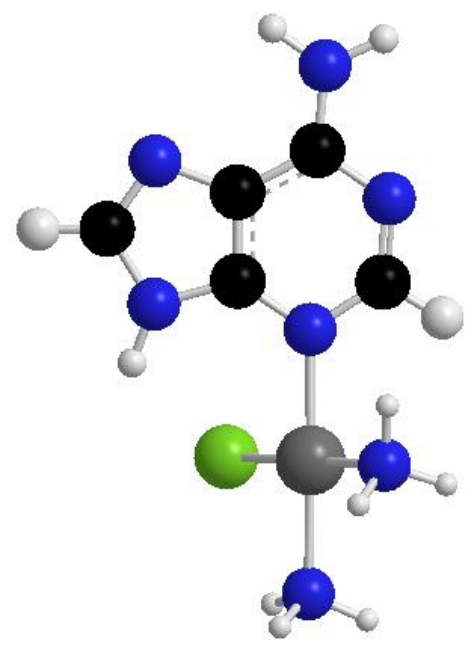

$\operatorname{PtAN3}(0.0 ; 0.0)$

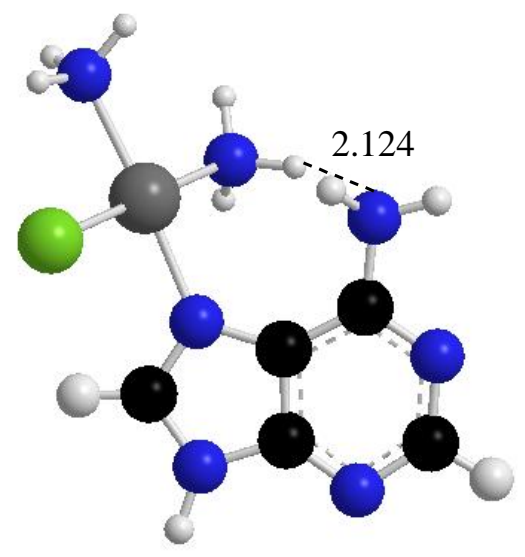

PtAN7 $(+13.3 ;+8.8)$

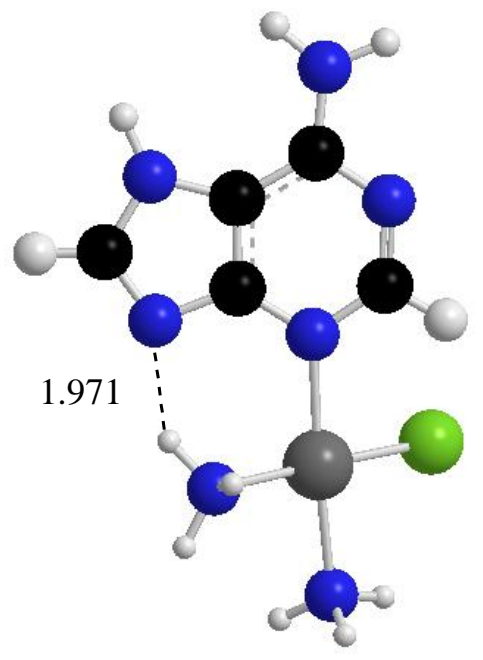

PtAN3N7t $(-8.9 ;+0.7)$

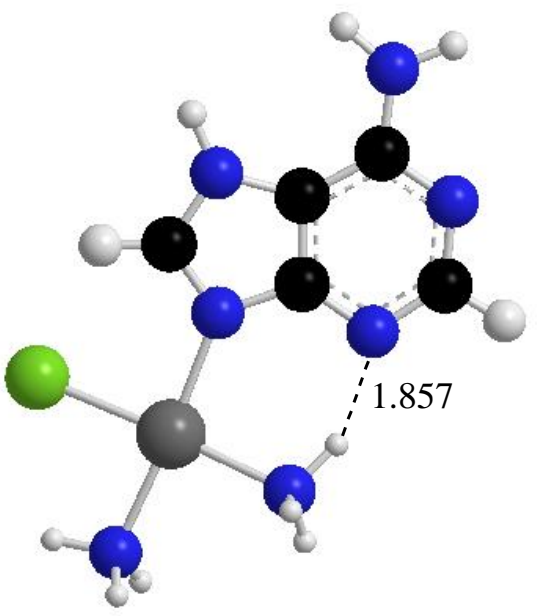

PtAN9N7t $(-13.7 ;+0.6)$

Figure 5. Geometries and relative free energies $\left(\mathrm{kJ} \mathrm{mol}^{-1}\right.$, in parentheses) for representative cis- $\left[\mathrm{Pt}\left(\mathrm{NH}_{3}\right)_{2}(\mathrm{~A}) \mathrm{Cl}\right]^{+}$structures calculated at the B3LYP/6-311G** level. Distances are given in Angströms. Relative free energies given in italic were obtained by using the Polarized Continuum Model (PCM) approach 


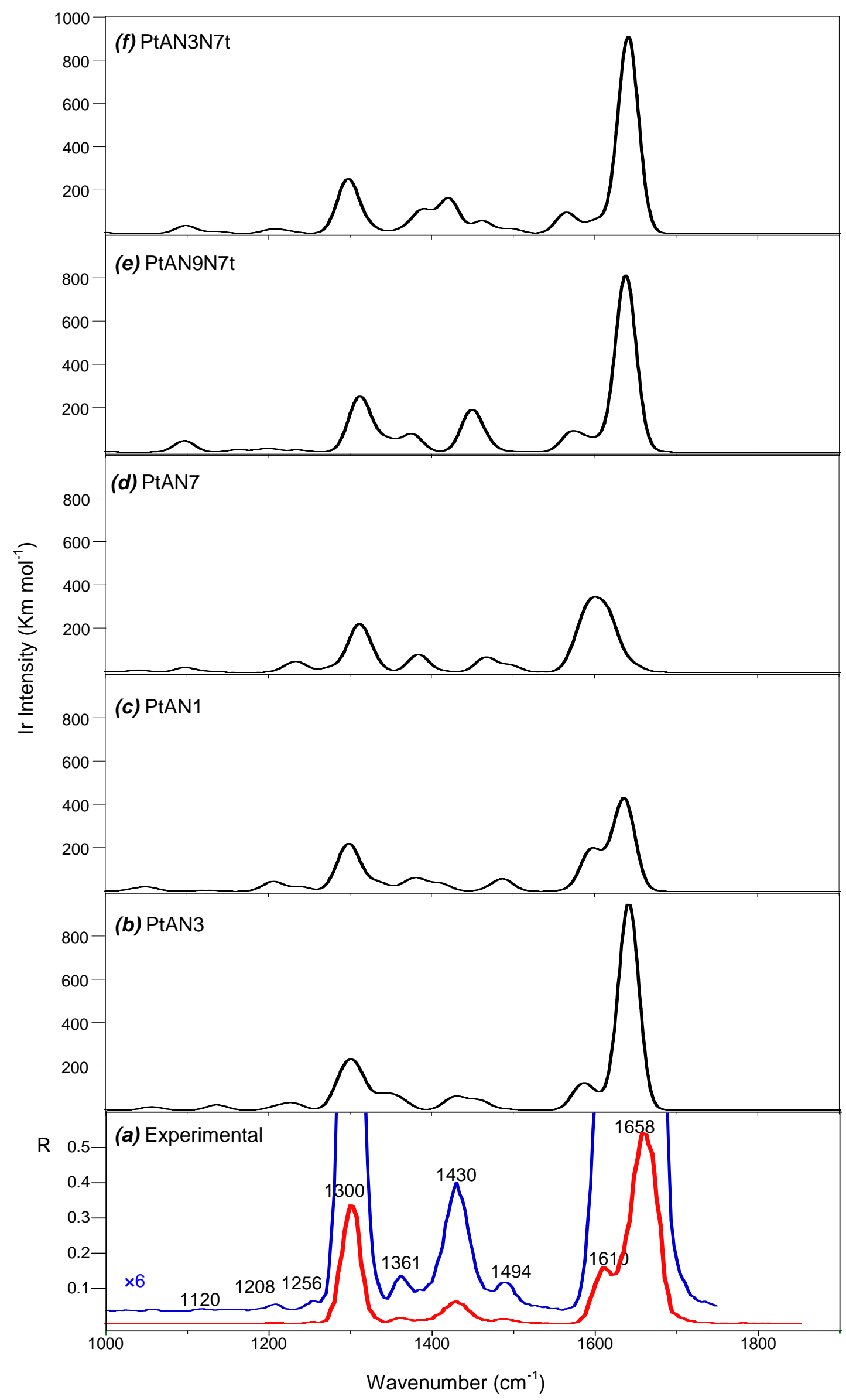

Figure 6. a) Experimental IRMPD spectrum of cis-[Pt( $\left.\left(\mathrm{NH}_{3}\right)_{2}(\mathrm{~A}) \mathrm{Cl}\right]^{+}$together with computed IR spectra of b) PtAN3, c) PtAN1, d) PtAN7, e) PtAN9N7t and f) PtAN3N7t, all calculated at the at the B3LYP/ 6-311G** level, in the spectral range of $1000-1900 \mathrm{~cm}^{-1}$ 


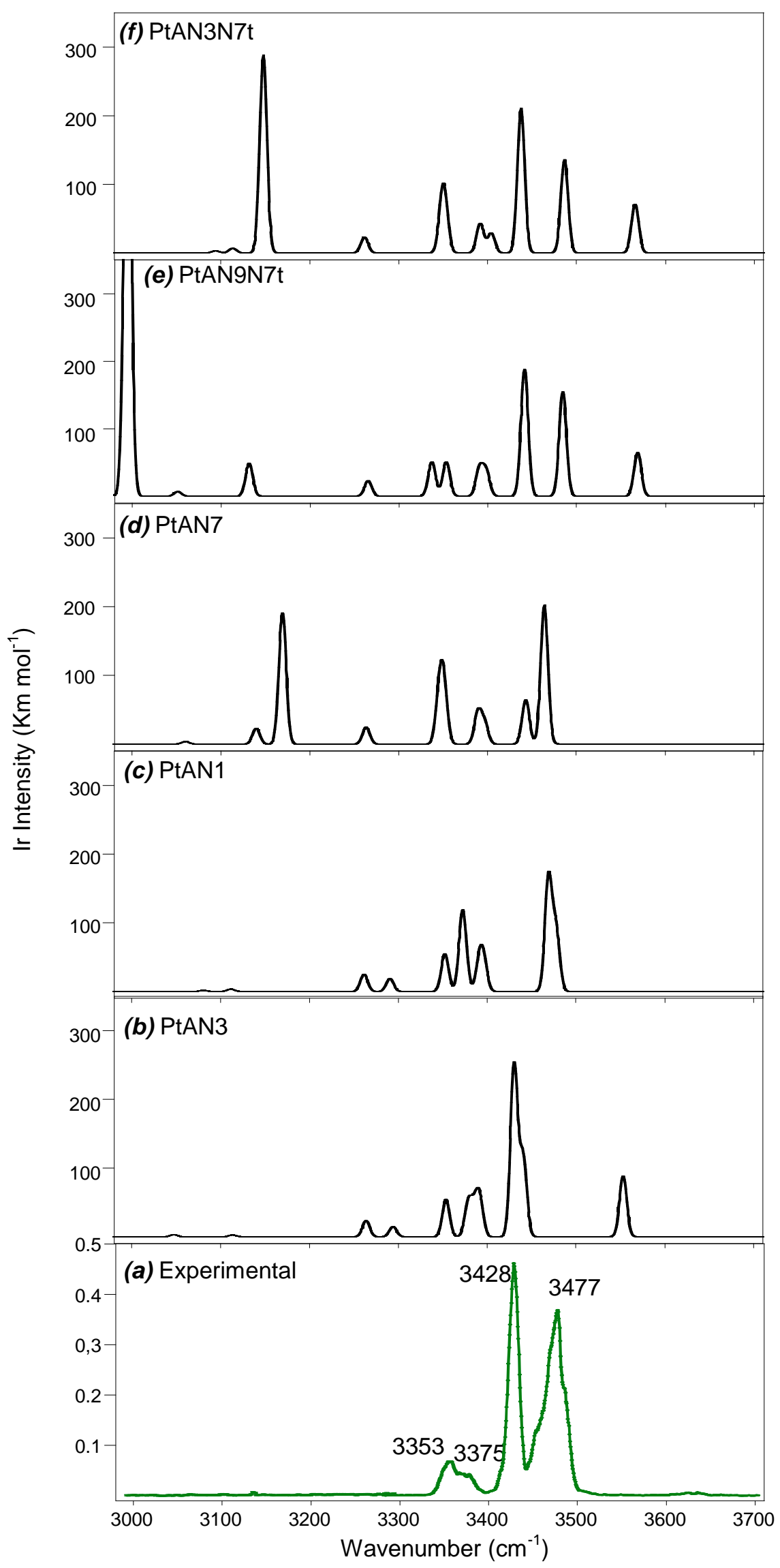

Figure 7. a) Experimental IRMPD spectrum of cis-[Pt( $\left.\left(\mathrm{NH}_{3}\right)_{2}(\mathrm{~A}) \mathrm{Cl}\right]^{+}$together with computed IR spectra of b) PtAN3, c) PtAN1, d) PtAN7, e) PtAN9N7t and f) PtAN3N7t, all calculated at the at the B3LYP/ 6-311G** level, in the spectral range of $3000-3700 \mathrm{~cm}^{-1}$. 


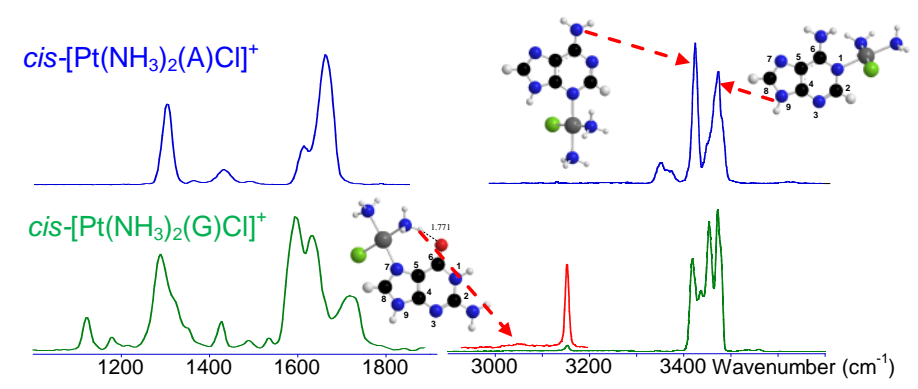

